\title{
The Role of the Distributor Network in the Persistence of Legal and Ethical Problems of Multi-level Marketing Companies
}

\author{
Claudia Groß $^{1} \cdot$ Dirk Vriens $^{1}$
}

Received: 7 June 2016/ Accepted: 24 April 2017

(c) The Author(s) 2017. This article is an open access publication

\begin{abstract}
Multi-level marketing companies (MLMs) such as Amway, Herbalife, or Tupperware differ from most other companies. They market their products and services by means of self-employed distributors who typically work from home, sell products to end consumers, and recruit, motivate, and educate new distributors to do the same. Although the industry's growth seems to illustrate the attractiveness of MLMs, the industry has been facing several legal and ethical problems. In this paper, we focus on these problems and argue that an extended MLM model may help us to understand why such problems continue to occur, despite the countermeasures that have been implemented. By explicating how problems relate to a specific but often overlooked characteristic of MLMs, i.e., the socalled distributor network, we provide an extended understanding of (a) MLMs' mode of operation, (b) the sources of their legal and ethical problems, and (c) the reason that currently implemented and suggested countermeasures may not suffice. Moreover, based on our extended understanding of MLMs and their problems, we propose additional countermeasures.
\end{abstract}

Keywords Corporate ethics $\cdot$ Illegal behavior $\cdot$ Multi-level marketing · Unethical behavior

Dirk Vriens

d.vriens@fm.ru.nl

Claudia Groß

c.gross@fm.ru.nl

1 Institute for Management Research, Radboud University Nijmegen, PO Box 9108, 6500 HK Nijmegen, The Netherlands

\section{Introduction}

Multi-level marketing companies (MLMs) such as Avon, Amway, Herbalife, Mary Kay Cosmetics, Tupperware, and Vemma represent a growing industry worldwide (WFDSA 2016). In 2015, more than 103.3 million people around the world worked for MLMs, creating a retail turnover of approximately 183.7 bn US Dollars (for worldwide as well as regional numbers see WFDSA 2016). Typically, selfemployed, unsalaried, and independent MLM distributors are entitled to earn money in two ways (Brodie et al. 2004). First, by selling company products 'directly' to consumers, i.e., on a 'face-to-face [basis] ... away from a fixed retail location' (Peterson and Wotruba 1996, p. 2). Typical products and services sold to non-members ('ultimate consumers') are, for example, cosmetics, energy supply, food storage products, insurances, jewelry, loans, nutritional supplements, phone contracts, and wine (DSN 2012). Making money this way is characteristic for so-called 'direct selling organizations'- to which MLMs belong. A second way for MLM distributors to earn money is by recruiting, training, and motivating new distributors, and building a so-called 'downline' of members (Brodie et al. 2002). When downline members buy products from the company or recruit new members to do the same, the recruiters (the 'upline') earn override commissions on the product purchases of their downline. This results in a 'hierarchy of recruiters/sellers' which is distinctive of MLMs. Almost all direct selling organizations employ this 'multi-level marketing' structure (DSN 2012), which means that almost all direct selling organizations are also MLMs.

The attractiveness of multi-level marketing has several reasons: for companies it seems an attractive marketing strategy, consumers appreciate buying products from 
friends and family members, and for distributors MLM companies offer an easy way to try an entrepreneurial experience as well as a way to buy products cheaper. ${ }^{31}$ Whereas other authors have described and explained several advantages of the industry (Albaum and Peterson 2011; Brodie et al. 2004; Crittenden and Albaum 2015), this article focuses on its problems: since their very beginnings in the 1920s of the last century, the industry has had to face and deal with problematic behavior on the individual distributor as well as the company level (e.g., see Biggart's historical overview chapter 2, 1989). These problems include that (1) some MLM companies operate as de facto pyramid schemes (Juth-Gavasso 1985; Keep and Vander Nat 2014; Koehn 2001; Vander Nat and Keep, 2002; Walsh 1999b), (2) income opportunities are misrepresented (Groß and Jung 2009; Herbig and Yelkurm 1997; Koehn 2001; Taylor 2014; Walsh 1999a), (3) customers are harmed by exaggerated and/or illegal product claims (Koehn 2001), (4) distributors misuse their friends and family members to earn money (Bloch 1996; Koehn 2001; Lan 2002; Walsh 1999a), and (5) that some MLMs have cult-like organizational cultures (Bromley 1998; Groß 2010) that restrict their members' ability to reflect on the (ethical) quality of the company's business practices.

To overcome these problems, governments have taken regulatory actions. ${ }^{28}$ Direct selling associations, on their part, have created voluntary industry Codes of Ethics (DSE 2015; Seldia 2011; WFDSA 2008) ${ }^{3}$ and set up complaint procedures. $^{2}$ Although such measures have prevented misbehavior (Chonko, Wotruba and Loe 2002; Wotruba, Chonko and Loe 2001), the industry's legal and ethical problems have not been resolved yet as the temporary shutdown of Vemma in the USA in $2015^{4}$ and the Herbalife settlement in $2016^{1}$ demonstrate (see for further evidence "Appendix"). Accordingly, critical commentators of the industry have suggested that central aspects of MLMs' business model need to be changed. ${ }^{5}$ The US Federal Trade Commission (FTC), for example, has asked 'multi-level marketers ... to take effective action to halt the practices that understandably damage the credibility of the whole industry' (Ramirez 2016, p. 2). Suggestions include changing the business model from a focus on recruiting to a focus on product sales (Ramirez 2016), ${ }^{28}$ prohibiting the recruitment of new distributors by existing distributors ${ }^{6}$, reducing the number of levels within the "hierarchy of distributors' (Hyman 2009; Peterson and Albaum 2007; Sparks and Schenk 2006), and asking MLMs to disclose what they actually are: 'buying clubs' instead of opportunities to become rich (Hyman 2007, 2009).

Although we agree that such measures would indeed help to alleviate certain problems, we seek to add a different factor to this discussion here. We argue that existing measures may not be able to solve all legal and ethical problems, because they do not, in our view, pay enough attention to one specific and important characteristic of MLMs, which we call the 'distributor network' (DN). Often it is by means of this network, rather than by MLM headquarters, that distributors are trained and socialized in particular (both ethically and legally sound as well as problematic) ways. Although it has been analyzed that this DN influences the behavior of individual distributors (Biggart 1989; Lan 2002; Pratt 2000a,b), its ways of operating and its relevance for the persistence of MLMs' problematic behavior has received little explicit attention. In this paper, we argue that we need: first, a better conceptualization of the DN; second, a better understanding of how the DN relates to headquarters, individual distributors, and organizational 'outsiders'; and third, more insight into DN's role in the occurrence and persistence of problems. The main goal of our conceptual paper is to introduce an extended model of MLMs that includes the DN. In addition, we set out to show that such a model can indeed shed more light on the sources of MLMs' ethical and legal problems, explain why some problems persist despite implemented countermeasures, and help to find new countermeasures.

We structure our paper as follows. In the next section, we first share our observation that several legal and ethical problems of MLMs persist despite implemented countermeasures. To do so, we provide an overview of problems and countermeasures. In "Understanding how MLMs operate: A 'prevailing' and an 'extended' model' section, we first discuss the 'prevailing model' of MLMs and introduce our extended model. In "Why legal and ethical problems persist, despite exiting countermeasures " section, we revisit the discussed problems and implemented countermeasures and argue why our extended model may help to better understand why certain problems persist despite the formulated mitigating measures. In "Reflecting on additional countermeasures" section, we reflect on additional countermeasures. In "Conclusion" section, we conclude and suggest avenues for further research.

\section{The Legal and Ethical Problems of MLMs and Existing Measures to Deal with them}

Since the beginnings of the industry in the early twentieth century, a broad range of actors, such as industry associations, consumer watchdogs, and governmental agencies, have dealt with problems of the MLM industry. The first code of ethics for MLM, for example, was already created in the 1930s by an early industry association in the USA, responding to the public critique on how companies and their distributors operated (Biggart 1989). Although many actors have discussed industry problems, academic 
research into MLMs' legal and ethical problems has been rather limited; Koehn (2001), to our knowledge, is the only author providing an overview.

As the paper's goal is to argue that an extended MLM model may help us to understand why MLMs' legal and ethical problems persist despite existing countermeasures, we first provide, in this section, an overview of the legal and ethical problems and existing countermeasures (see Table 1).

Our overview differs from earlier research (notably Koehn's 2001) in four ways. First, we include existing countermeasures. Second, as academic research is rather limited, we supplement academic insights with a broad range of empirical sources, including consumer-related research, publications by watchdogs, media and governmental organizations (see "Appendix"). Third, we extend Koehn's (2001) overview of existing problems by adding a fifth problem category (see last row Table 1). Fourth, we briefly indicate why business practices that seem ethically neutral in non-MLM contexts become ethically problematic in the context of MLMs.

\section{Illegal Pyramid Schemes}

An investigation of the US Federal Trade Commission into the Amway Corporation in the 1970s spurred the debate of whether MLMs were illegal pyramid schemes. In its 1979 defense, Amway produced several guidelines to mitigate the problems, convincing the FTC that it was operating legally. Ever since, however, researchers (Juth-Gavasso 1985; Keep and Vander Nat 2014; Koehn 2001; Vander Nat and Keep 2002; Walsh 1999a) as well as consumer advocates $^{8}$ have questioned whether the 1979 FTC decision, the legal standards that have been developed since

Table 1 Overview of legal and ethical problems of MLMs and existing countermeasures

\begin{tabular}{|c|c|c|c|}
\hline \multicolumn{3}{|c|}{ Legal and ethical problems of MLMs } & \multirow[t]{2}{*}{ Existing countermeasures } \\
\hline Problem category & Dimensions & Ethical dimension & \\
\hline $\begin{array}{l}\text { 1. Illegal pyramid } \\
\text { schemes }\end{array}$ & $\begin{array}{l}\text { Focus on recruitment instead } \\
\text { of product sales } \\
\text { Substantial upfront fees } \\
\text { Inventory loading }\end{array}$ & $\begin{array}{l}\text { Misleading (future) distributors by untruthful } \\
\text { promises }\end{array}$ & $\begin{array}{l}\text { 10-customer rule } \\
70 \% \text { rule } \\
\text { Low upfront fees } \\
\text { Restricting levels for override } \\
\text { commissions } \\
\text { Buyback policies, regulated by } \\
\text { governmental rules and Codes of } \\
\text { Ethics (company and industry level) }\end{array}$ \\
\hline $\begin{array}{l}\text { 2. Misrepresenting } \\
\text { the business }\end{array}$ & $\begin{array}{l}\text { Earnings misrepresentations } \\
\text { Misrepresentation of selling } \\
\text { and recruitment potential }\end{array}$ & $\begin{array}{l}\text { Misleading (future) distributors by untruthful } \\
\text { promises }\end{array}$ & $\begin{array}{l}\text { Industry Codes of Ethics } \\
\text { Company Codes of Ethics } \\
\text { Governmental rules }\end{array}$ \\
\hline $\begin{array}{l}\text { 3. Harming } \\
\text { customers }\end{array}$ & $\begin{array}{l}\text { Providing misleading product } \\
\text { information to (internal and } \\
\text { external) consumers } \\
\text { Product sales by laymen } \\
\text { Exploiting the professional- } \\
\text { client relationship }\end{array}$ & $\begin{array}{l}\text { Misleading customers by untruthful promises } \\
\text { Misusing trust in professional settings and } \\
\text { reducing professional independence }\end{array}$ & $\begin{array}{l}\text { Governmental rules preventing product } \\
\text { misrepresentations } \\
\text { National rules and Codes of Ethics for } \\
\text { health professionals }\end{array}$ \\
\hline $\begin{array}{l}\text { 4. (Mis-)using } \\
\text { trust in private } \\
\text { social relations }\end{array}$ & $\begin{array}{l}\text { Instrumentalization of private } \\
\text { social relations }\end{array}$ & $\begin{array}{l}\text { Restricting consumers' autonomy } \\
\text { Misusing trust in private social relations }\end{array}$ & $\begin{array}{l}\text { Buyback policies, regulated by } \\
\text { governmental rules and Codes of } \\
\text { Ethics (company and industry level) } \\
\text { Easy cancelation policies by industry } \\
\text { associations' Codes of Ethics) } \\
\text { Fair treatment of customers, regulated } \\
\text { by industry associations' Codes of } \\
\text { Ethics }\end{array}$ \\
\hline $\begin{array}{l}\text { 5. Total } \\
\text { institutions }\end{array}$ & $\begin{array}{l}\text { Socialization along company } \\
\text { beliefs } \\
\text { Instrumentalization of spiritual } \\
\text { needs for economic purposes }\end{array}$ & $\begin{array}{l}\text { Restricting ability for reflection on ethical } \\
\text { quality of business practices and } \\
\text { endangering distributors' moral autonomy }\end{array}$ & $\begin{array}{l}\text { Company rules for how to educate } \\
\text { members } \\
\text { Watchdog organizations in some } \\
\text { countries }\end{array}$ \\
\hline
\end{tabular}


then, and MLMs self-regulation efforts are sufficient to prevent such illegal practices (see for a comparable recent case the 2016 Herbalife settlement; Ramirez 2016 ${ }^{1}$ ).

Whereas the distinction between legal and illegal practices needs to be made per company (Keep and Vander Nat 2014), three main characteristics are used to distinguish legal MLM companies from illegal pyramid schemes (Keep and Vander Nat 2014; Koehn 2001; Vander Nat and Keep 2002; Walsh 1999a). The first and most important characteristic is that illegal schemes focus on growth by recruiting new members instead of growth by selling products to clients. Like the classic Ponzi schemes, systems based on growth by recruiting are unsustainable. When the number of new recruits increases, market saturation is quickly reached. As a result, it gets more and more difficult for (new) members to earn money by recruiting and thus to gain a return on their investment. Whereas the increase of organizational members might be an ethically neutral business practice in many situations, in the case of pyramid schemes it is problematic (and illegal). The reason is that consumers join these systems based on untruthful promises. First, consumers are promised an income opportunity. However, income is very unequally distributed (Hyman 2007; Lorenz and Mazzoni 2010) and growth based on recruitment implies that by exponential progression only those at the top can earn back their investment (Bosley and McKeage 2015; Pareja 2008). Second, consumers are promised that everyone can reach the top, not only the first to join. However, research indicates that those very few members who earn money are the early adopters, whereas those who join later lose money (Bosley and McKeage 2015). To summarize, distributors are misled as they are made to expect something different than what they encounter (Hyman 2009).

A second feature of illegal schemes refers to the substantial upfront fees for entering the company and/or the pressure for existing distributors to invest large sums into motivational material and seminars. Investing money for starting up a business is a normal and as such ethically neutral practice. In the case of pyramid schemes, however, it is ethically problematic. The reason is the same as with growth by recruiting, i.e., deceptive information (Hyman 2009). Consumers invest because they are promised that they can expect to earn (far) more than they invest. As explained above, this is not the case in schemes that are based on recruiting (Bosley and McKeage 2015; Hyman 2007; Lorenz and Mazzoni 2010; Pareja 2008). Thus, the deception does not lie in asking (future) distributors to make (up-front) investments. The problem is that distributors make these investments based on wrong information.

A third characteristic of illegal pyramid schemes is inventory loading by internal consumption (Keep and Vander Nat 2014; see also Muncy 2004). Members are enticed to purchase products, which they are neither able to consume nor sell (in a reasonable amount of time). Whereas some authors argue that internal consumption is a widespread and ethically neutral business practice (Albaum and Peterson 2011; Crittenden and Albaum 2015; Peterson and Albaum 2007), the ethical problem - once more-is not the business practice as such. The problem arises in the context of MLMs that connect internal consumption with a business opportunity, i.e., the hope to earn money. The then-chairwoman of the FTC explained in 2016: 'When a product is tied to a business opportunity, experience teaches that the people buying it may well be motivated by reasons other than actual products demand' (Ramirez 2016, p. 6).

At some MLMs, members are enticed to buy products a) to reach a certain and/or higher status level, including higher commissions or higher paybacks from purchases or b) to be entitled to certain commissions. For example, to earn commission on one's group turnover, one is required to also purchase a certain amount of products in the respective month. In both cases, buying company products is stimulated by income motives, not by consumption needs. This is, we argue, a very particular form of 'internal consumption' that does not, to our knowledge, exist outside the MLM context. 'Internal consumption' at MLMs thus turns into an ethically (and legally) problematic practice under two conditions: (a) when commission systems entice distributors to buy more than they need themselves and (b) when the commission system entices distributors to purchase more products than they can sell (in a reasonable amount of time). Companies that have only few end consumers and a high level of internal consumption are actually buying clubs (Hyman 2009). When such companies promote membership as an income opportunity, they misrepresent their true nature.

The ethical (and legal) problem is thus deception: distributors join a company to earn money, but overspend by buying company products they neither need nor are able to sell (for empirical evidence see for example Bhattacharya and Mehta 2000; Cahn 2006; Pratt 2000a; Ramirez 2016). ${ }^{11,12,13}$

To avoid the described legal and ethical problems, governments have set up countermeasures, partially building on Amway's FTC defense in 1979. The 'tencustomer rule,' for example, originally introduced by Amway, is a measure to ensure that distributors do not only recruit but actually sell products to at least ten ultimate users per month (see also Keep and Vander Nat 2014). The so-called ' $70 \%$ rule' asks distributors to sell at least $70 \%$ of what they buy from the company. The rule is meant to (a) prevent inventory loading, (b) prevent a focus on recruiting, and (c) support the sales of products to end consumers as such sales ensure a sustainable form of income to distributors. In addition, many MLM companies 
restrict the amount of downline levels for which individual distributors receive override commissions. This solves, according to a several authors (Peterson and Albaum 2007; Sparks and Schenk 2006), the problem of exponential progression and unsustainability. To prevent high upfront costs, Industry Associations promote that 'any fee shall represent reasonable value,' i.e., relating to the value 'of the materials, products, or services provide[d] in return' (Seldia 2011, p. 25; see also DSE 2015; WFDSA 2008). Finally, industry associations (DSE 2015; Seldia 2011; WFDSA 2008) and governments ${ }^{9}$ have set up buyback policies to ensure that returning inventory is easy and financially sound. However, despite these countermeasures, empirical evidence mounts that at some MLMs the described problem persists (Babu and Anand 2015; Bosley and McKeage 2015; Keep and Vander Nat 2014; Koehn 2001; Taylor 2014). ${ }^{7,8,10}$ As the FTC chairwoman concludes in her keynote remarks to the Direct Selling Association Business and Policy Conference in 2016, the MLM industry 'should undertake [more] in order to operate lawfully and prevent consumer harm' (Ramirez 2016, p. 21).

\section{Misrepresenting the Business Opportunity}

The attractiveness for people to join an MLM is fueled by promises to 'get rich quickly' and the ease of selling products, i.e., the 'unlimited' market potential (Koehn 2001). While misrepresenting the true nature of a business opportunity is related to pyramid schemes (see above), it also seems to be a common practice in 'legal' MLMs in the sense that relevant information about the business opportunity is not presented truthfully or withheld (see accounts by former distributors, such as Andrews 2001; Smith 2013; Sonnabend 1998; for research see Groß 2008; Koehn 2001; Muncy 2004; for consumer advocates, see "Appendix"11,12,13; for FTC see Ramirez 2016).

Whereas overstating the quality of products and services might be a common and also ethically neutral business practice, in the MLM context overstatements seem to be so widespread, that they have been discussed as ethically problematic (Koehn 2001). Most MLMs present working for them as an attractive 'business opportunity,' enabling distributors to earn a handsome amount of money, either part time or full time (Koehn 2001). Legal, but still recruitingoriented companies seek to make newcomers believe that recruiting others is the silver bullet to earning a substantial amount of money or to becoming rich in a rather short time (Groß and Jung 2009; Koehn 2001; Walsh 1999a). Newcomers and existing distributors are motivated by exemplary calculations demonstrating the ease of recruitment, the ease of selling, and the high market potential. In motivational material (handbooks, leaflets, videos, etc.) and seminars, success stories by those who 'made it' are presented (Ramirez 2016). ${ }^{14,15}$ The emphasis is on how simple the business is. This promise is ethically problematic in the case of the MLM industry as actual numbers demonstrate the low likelihood of success, the low average income, and the unequal distribution of income (Biggart 1989; Hyman 2007; Lorenz and Mazzoni 2010; Pratt 2000a; Ramirez 2016; Taylor 2014). ${ }^{11,12,13}$ It is ethically problematic to inflate promises and not provide relevant and accurate information about the business opportunity, as these constitute forms of deception (Hyman 1990, 2009).

The problem of misleading distributors is aggravated when companies 'target the unemployed and income-deprived population[s]' (Franco and Gonzalez-Perez 2016, p. 40; for an opposite point of view in the context of developing countries see Fadzillah 2005, Scott et al. 2012) and/or focus on prospects who 'are desperate for a job' (Koehn 2001 p. 156), i.e., socially vulnerable groups. These are people with an unfavorable status on the job market, such as mothers with (small) children (Biggart 1989), disabled people (Friedner 2014, 2015), or immigrants (Groß 2008). They are attracted by the promise that everyone can succeed in the business: a promise that lacks the material substance for most distributors, as described above.

To prevent the misrepresentation of earnings and the market potential of products, companies and industry associations have included rules in their Codes of Ethics for providing 'accurate and complete' information only (Seldia 2011, p. 23; see also DSE 2015; WFDSA 2008). Such rules are in line with federal law in expecting companies to act as 'bona fide sales organizations which market bona fide products to consumers' (Babener, 1998). However, as the FTC states, more needs to be done. MLMs need, for example, 'effective monitoring programs in place to ensure participants do not convey misleading claims or present unrealistic 'lifestyle' testimonials that are true for only a tiny minority of participants to prospective participants $^{12-17,}$ 28' $^{\prime}$ (Ramirez 2016).

\section{Harming Customers}

In relation to customers, whether internal or external customers, two central ethical concerns can be found in academic and popular literature. First, companies and distributors are found to misrepresent the value and quality of products, and to provide questionable advice and/or make illegal claims (Groß 2008). ${ }^{18,20,25}$ Biggart (1989, p. 110) explains that some MLMs suggest their products are 'special and have the power to transform their users in important ways,' such as make them happier, healthier, better parents and better human beings. Whereas the tendency to exaggerate might be typical for the marketing activities of most companies, MLMs seem to be 
particularly prone to overstating product qualities (Biggart, 1989). ${ }^{25}$ This might be related to the fact that headquarters has little control over distributors' statements that often take place in private settings, i.e., distributors' or clients' homes (Juth-Gavasso 1985). ${ }^{20}$ Moreover, MLMs' profit formula and marketing strategy 'everyone can join' implies that, for example, nutritional supplements and nonprescription health products are sold by laymen who might simply lack the knowledge for giving good advice. Although a lack of knowledge can occur in any job or trade, and as a consequence might lead to incomplete, bad, or even harmful advice, the ethical risks connected with lacking knowledge are built into how MLMs work, i.e., non-experts selling products and providing advice. Whoever signs an agreement with a company such as Amway (Nutrilite products), Herbalife, Nikken, ProHealth, Usana, Tahitian Noni, or Vemma becomes a 'health advisor.' In companies like OVG Holding AG, Primerica, Swiss Life Select, non-experts become advisors for wealth creation or retirement building. Whereas people in any job or profession might (sometimes) lack the knowledge to do their job properly, at MLMs distributors are not even required to have any knowledge or education. The in-house trainings provided by MLMs themselves cannot compare to company-independent, certified professional education on health or financial issues. Accordingly, the risk that distributors might (unwillingly) give limited or wrong information and useless or bad advice to consumers is real in MLMs.

A lack of truthfulness becomes particularly problematic, when distributors make illegal claims, for example that nutritional supplements cure all sorts of severe health problems. In its investigation into 62 companies selling nutritional supplements that are members of the Direct Selling Organizations, the watchdog organization TINA found more than 1000 problematic product claims made by 60 different companies. ${ }^{25}$ Here, distributors-intentionally or unintentionally-misuse customers' trust (DiMaggio and Louch 1998). In addition, they take advantage of customers' search for a way out of their misery. Many national laws clearly prohibit such claims ${ }^{19}$, but consumer advocates ${ }^{20}$ as well as the FTC (Ramirez 2016) observe that MLMs' sales actually prosper by such practices. Headquarters, on the other hand, might dodge responsibility by putting the blame on 'a few black sheep' among their independent distributors ${ }^{20}$ (for the case of Amway in the USA in the 80s see Juth-Gavasso 1985; for dodging responsibility in general, see Jackall 1988).

A second ethical problem in the distributor-client relationship has been labeled 'exploiting the professional-client relationship' by Koehn (2001). In the USA, health professionals, (e.g., physicians, dentists, or dermatologists) promote and sell nonprescription health products (from MLMs or other companies) in their offices (Dumoff 2000;
Ogbogu et al. 2001; Whitaker-Worth et al. 2012). However, it is ethically problematic when distributors exploit their professional status and their trust relationship with their clients to increase their profit. When health professionals earn more money by prescribing 'own' products, their independence is at risk. Under these circumstances, they might not provide the best advice and treatment to patients, but the treatment with the highest profit margin. Thus, as Koehn (2001, p. 159) points out, an economic interest thwarts the 'professional's ability to help the client in accordance with his public pledge to do so. ${ }^{29}$

Aside governmental rules prohibiting certain health claims as illegal ${ }^{19}$, a variety of countermeasures exist to prevent the issue of harming customers. These countermeasures relate to health professionals in general as well as to those who are MLM representatives. In the USA, for example, the sales of health-related products by physicians is allowed under certain conditions only (AMA 2010; Whitaker-Worth et al. 2012). In some European countries, professional ethical standards prohibit office-based dispensing of health-related products altogether (see for example Germany Bundesärtzekammer 2015). However, as a consumer advocate documentary on LifePlus in Germany illustrates, Medical Boards may simply lack the financial resources to investigate cases of misuse. ${ }^{11}$ So, whereas different national measures exist to mitigate the described problem, the tension between providing independent professional advice and earning money remainsfor MLM distributors, employees of non-MLMs, and nonMLM entrepreneurs.

\section{(Mis-)using Trust in Private Social Relations}

A fourth problem, often discussed implicitly in existing research, is the use and misuse of trust in private social relations. Customers and (prospective) distributors are mostly approached by people they know: family members, friends, acquaintances, or former classmates (Biggart 1989; Friedner 2015; Grayson 2007; Pratt and Rosa 2003). Enthusiastic distributors seek to promote their business almost everywhere, whether it be at their best friends' dinner party, parent-teacher meetings, or leisure club activities. Whereas we agree with Albaum and Peterson (2011) that it is a widespread practice to talk to friends and relatives about one's own business, we argue that it is at least an ethically sensitive practice. That is, selling products and promoting a business opportunity in private settings entails using and potentially misusing situations of relatively high trust (DiMaggio and Louch 1998; Kong 2003). Private social ties can make it more difficult for friends and family members to refuse an offer to join a meeting, buy products, or get involved in a company (Bhattacharya and Mehta 2000; Biggart 1989; Bloch 1996; 
Friedner 2015; Lan 2002; Pratt and Rosa 2003; Walsh 1999a). Accordingly, consumers' autonomy-i.e., their autonomy to make choices based on own interests, needs, wishes, etc., instead of displaying socially desirable conduct-is restricted (for consumer behavior in embedded markets see Frenzen and Davis 1990). This risk, we would argue, is present in any form of selling. However, it manifests itself in a particular intensive way at MLMs because MLMs are based on using private relations. Whereas nonMLM sales people might, next to other marketing channels, choose to also approach their friends and relatives, for most MLMs, approaching private relations is the central marketing strategy and the starting point for (new) distributors (Sparks and Schenk 2001, 2006). Accordingly, at MLMs the risk of misusing trust is higher in comparison with other sales organizations as the marketing activities take place far more often in situations of trust.

An additional reason why selling and recruiting among friends and family members is ethically sensitive is the particular context of the MLM industry. The risk of (mis)using social trust is aggravated in conjunction with the above described problems of 'misrepresenting the business' and 'harming customers.' As new distributors often approach friends and family members (see sources above), the social harm done when the business or product qualities are misrepresented might be perceived as particularly serious (Scheibeler 2004; Smith 2013; Walsh 1999a).

Several countermeasures have been proposed to deal with the issue of misusing trust in private social relations. Industry associations (DSE 2015, p. 9; Seldia 2011, p. 13; WFDSA 2008, p. 8) have, for example, implemented buyback and cancelation policies (see also governmental rules ${ }^{9}$ ). These seek to ensure that returning inventory is easy and financially sound and that new distributors can easily withdraw their enrollment with a company. In addition, Industry Codes of Ethics seek to regulate the fair treatment of customers, for example by respecting their privacy or their lack of commercial experience (DSE 2015, p. 9; Seldia 2011, p. 13; WFDSA 2008, p. 9). However, these rules do neither change the central marketing strategy of MLMs, i.e., their focus on the 'warm market,' nor do they change the ethical sensitivity connected to using trust in private social relations. As such, these rules do not prevent the misuse of trust nor do they deal with the social obligation people may feel toward distributors they know (Kong 2003).

\section{Total Institutions: Colonizing Every Aspect of Distributors' Lives}

MLMs are well known for their ability to create an enthusiastic as well as a cozy and family-like atmosphere. They are widely described as companies where members and prospects are encouraged to believe in themselves, cheer each other, and envision a better future for themselves and their families (Biggart 1989; Bone 2006; Cahn 2006; Friedner 2014, 2015; Groß 2008; Krige 2012; Lan 2002; Pratt 2000a, b; Sparks and Schenk 2001). Research on the effects of transformational leadership in an MLM company shows that distributors who ascribe a higher purpose to their work are more satisfied as well as more financially productive (Sparks and Schenk 2001). Other studies have shown (Groß and Haunschild 2013; Lan 2002) how a strong belief in a company is supported by constant mutual confirmation among members. Mechanisms are frequent, sometimes daily, phone calls between upline and downline members, and regular local, regional, and (inter)national meetings and extravaganzas. In some MLMs, distributors are not only taught how to recruit others, but also what a fair and just society is (Groß and Haunschild 2013), and how to feel superior to critics of the company (Lan 2002). Lan (2002 p. 177) concludes that exactly because MLMs and their members are often confronted with criticism by non-members, '[d]istributors need each other to constantly confirm their belief in the moral values of direct selling and its promise of future success.'

According to Bromley (1998), MLMs such as Amway, Mary Kay Cosmetics, Herbalife, A. L. Williams Insurance, Tupperware, Shaklee, and Nu Skin in the USA, are particularly active in nurturing a strong moral self-perception. Bromley (1998) calls them 'quasi-religious corporations' as they do not merely offer a job, but promise to solve problems that are part and parcel of living in a differentiated, modern society. These MLMs represent themselves as a cure-all, i.e., a means to combine work and family, strive for a greater good, and create a better society at the same time (Cahn 2006; Droney 2016; Groß 2010; Gu 2004; Pratt 2000a; Pratt and Rosa 2003).

Whereas Sparks and Schenk (2001) see a positive link between the belief in higher-order motives and distributors' financial performance, other academic research (Bone 2006; Cahn 2006; Groß 2008; Pratt 2000a; Pratt and Rosa 2003) and consumer advocates ${ }^{12}$ point out that for most distributors these promises simply remain unfulfilled. When most distributors fail in creating an income, 'helping others' rather serves as a euphemism concealing distributors' own economic interests (Bloch 1996; Cahn 2006; Lan 2002), and family conflicts might even increase as distributors spend less time with their families due to business obligations (Bone 2006; Pratt and Rosa 2003). Besides the ethical problem of unfulfilled (material) promises (see above), a few researchers have pointed out that the strong corporate socialization might turn MLMs into 'total institutions' (Pratt 2000a, p. 59). In this case, companies colonize every aspect of members' lives: their current relationships, their world-view, and their hopes for their future (see also Groß 2010; Lips-Wiersma et al. 2009). 
At this point, we must note that the authors we mention in this section do themselves not explicitly label the socialization processes as ethically problematic. They do, however, treat them as such. The strong corporate socialization has been problematized by several authors in different MLM settings and national contexts [Bone 2006 (UK); Biggart 1989 (US); Bromley 1998 (US); Cahn 2006 (MEX); Groß 2010 (D); Krige 2012 (ZAF)]. As 'total institutions' (Pratt 2000a), for example, MLMs might undermine distributors' ability to critically reflect on the moral quality of the company's business practices. Restricting organizational members' ability for reflection and thus endangering their moral autonomy (Werhane 1999) might, we argue, in the light of the above described legal and ethical problems of the industry, be considered by itself an ethical problem. As described by the literature on the 'normalization of corruption' (Ashforth and Anand 2003; Ashforth et al. 2008), a strong corporate socialization might make distributors be unaware of ethically problematic aspects of their own as well of their company's behavior-again restricting and limiting their moral awareness. Thus, even though not explicitly discussed as an ethical problem in the academic MLM literature so far, we regard the described strong corporate socialization as ethically problematic.

That the strong socialization at some MLMs is regarded as problematic outside academia, is related to the accusation of some organizations being 'quasi-religious' or 'cultlike ${ }^{2122}$, and is related to the fact that some companies have actually set up guidelines to prevent such accusations. Amway, for example, explicates in its guidelines that (upline) distributors are not allowed to make spiritual, religious, or moral statements on stage or propagate a particular world view (Amway 2012, pp. 5-6). The effectiveness of such rules is open to discussion, however. In particular, the Amway Corporation has been criticized for its cult-like organizational culture and the strong socialization of its members (Andrews 2001; Butterfield 1985; Dean 1996; Sonnabend 1998; Scheibeler 2004). In some European countries, church-run 'cult-advice offices' occasionally provide advice to friends and family members who are concerned about how MLMs operate. ${ }^{22}$ However, as monitoring business companies is not the central task of these offices, they have only limited resources for and knowledge about the MLM industry.

All in all, a broad range of countermeasures by organizations, industry associations, and governments has been introduced to ensure the legal and ethical behavior of companies and its distributors. However, a range of problems persists. In the next two sections, we will elaborate on how a new, extended conceptualization of MLM companies might help to better understand what causes these problems and how they might be overcome.

\section{Understanding how MLMs Operate: A 'Prevailing' and an 'Extended' Model}

The main purpose of this paper is to better understand why ethical and legal problems of MLMs persist (for some MLMs) despite current countermeasures. In our view, an important reason is that the prevailing conceptualization of how MLMs operate is insufficient for a proper understanding of the problems. Moreover, countermeasures that are based on this insufficient understanding may miss the mark. To make our point, we first need to explain both the prevailing and the extended models of MLMs.

\section{The 'Prevailing Model' of MLMs}

Although no off-the-shelf, agreed-upon model of how MLMs operate exists in literature or practice, most commentators (regulators, academics, representatives of watchdog organizations) seem to have several 'MLM' constituents and relations between them in mind when describing MLMs (Brodie et al. 2002, 2004; Herbig and Yelkurm 1997; Peterson and Wotruba 1996). The three recurrent constituents are: MLM headquarters, independent distributors, and 'non-members.' Between these three constituents, usually three relations are implied. Below, we will briefly discuss these constituents and their relations. The 'prevailing model' consisting of these constituents and relations is what we call the 'main organization' in Fig. 1.

Headquarters, as the first constituent of MLMs, is responsible for all key business decisions (products, markets, etc.) and for defining and establishing corporate policies, such as the conditions for becoming a distributor (e.g., no requirements except legal age of majority), the legal status of distributors as self-employed, and the commission system for selling and recruiting. The second constituent refers to the self-employed distributors, who work from home, market company products, and/or recruit, teach, and motivate others to do the same. Although not part of the organization (yet), (prospective) clients and prospective distributors are normally included in explanations of how MLMs operate, thereby forming the third constituent in our model. They are approached, usually face-to-face, by distributors for buying products and/or joining the company.

Between these three constituents, three relations are normally described. The first relation is the one between the MLM headquarters and the individual independent distributors (R1 in Fig. 1). It refers to the formal agreement a distributor has with headquarters. It also refers to rules and regulations set by headquarters, such as the distributor agreement and the handbook regulating the rights (such as commissions) and duties (such as compliance to Code of 
Fig. 1 Prevailing model of MLMs: the 'main organization' consisting of three constituents and their relations

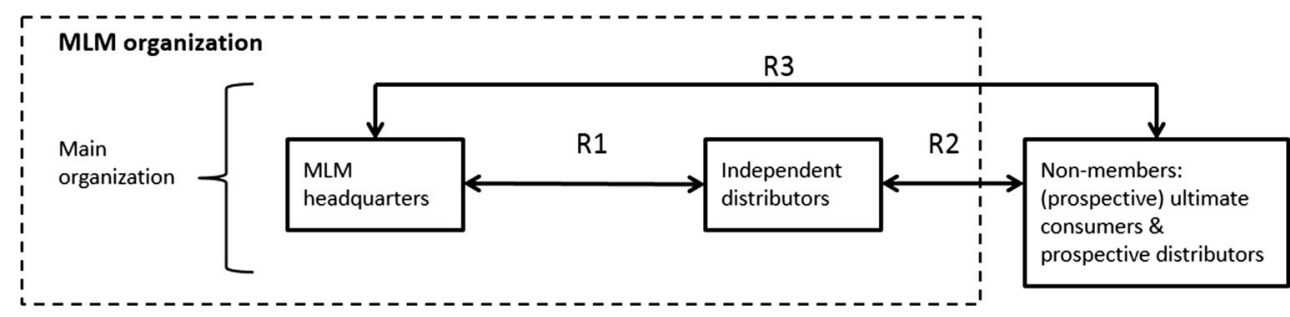

Ethics) of a distributor. This includes under which conditions distributors are entitled to a specific form of compensation (e.g., commission, bonuses, or discounts on products) and the ways distributors are entitled to represent the company, sell products, and recruit others. In addition, handbooks provide distributors with specific information, such as product information, how to declare taxes, and how to work as a distributor. Codes of Conducts provide guidelines for the way distributors should approach prospective clients and recruits. These codes include, for example, rules against income and product misrepresentations.

The second relation (R2 in Fig. 1) describes the interaction between independent distributors and prospective distributors and clients. This relation refers to the way distributors approach and deal with clients and how they recruit other distributors. These practices are, in part, governed by the rules and regulations featuring in relation R1. That is, headquarters expects that distributors behave appropriately toward non-members (relation R2) (as indicated in the rules and handbooks for and the formal agreements with independent distributors—which are part of relation $\mathrm{R} 1$ ).

The third relation (R3 in Fig. 1) is the one between MLM headquarters and non-members. Headquarters regulates, for instance, the rights of prospective and actual clients as well as the rights of prospective and newly recruited distributors in relation with headquarters. Examples include the abovementioned buyback policies for products or cancelation policies, such as a 'cooling off period' for customers to return their purchases (WFDSA 2008 , p. 8) and for new distributors the right 'to withdraw from his agreement without penalty and without giving any reason' (Seldia 2011, p. 25).

The prevailing model of MLMs allows us to understand how existing countermeasures are directed at the three relations of the main organization: first, rules such as the restriction of levels for which upline members can receive override commissions regulate the relation between headquarters and distributors (relation R1 in Fig. 1); second, Codes of Ethics, including guidelines for how to approach consumers, have been set up to ensure that distributors treat non-members in appropriate ways (relation R2); and third, rules such as buyback policies define headquarters' obligations toward end consumers (relation R3).
Based on the prevailing MLM model, it is difficult to explain why the broad range of existing countermeasures does not suffice to ensure ethical behavior. Here, Mintzberg's (1983) conceptualization of how different kinds of organizations need different kinds of coordination mechanisms may offer a way out. Whereas bureaucratic organizations can strongly rely on formalization to coordinate work, coordination in organizations 'where jobs are sensitive or remote ... must rely on training, and especially on indoctrination' (Mintzberg 1983, p. 41). We argue that MLMs are organizations that primarily rely on coordination by training and indoctrination. This claim is based on Biggart (1989), who argues that MLMs are not idealtypical bureaucracies (as distributors are legally independent, central bureaucratic elements such as formal employment contracts, fixed working hours, a prescribed tenure system, and the possibility for managers to exercise authority based on rational-legal authority are missing). Moreover, the selfemployed distributors work from 'remote' locations, i.e., private homes. Finally, as the literature referred to in Sect. 2 illustrates, jobs at MLMs can be categorized as ethically sensitive.

Given these coordination mechanisms of MLMs, one way of approaching the question why legal and ethical problems persist is by gaining a better understanding of training and 'indoctrination,' i.e., socialization (Schein 1990 ) at MLMs. Former distributors (Andrews 2001; Scheibeler 2004; Smith 2013; Sonnabend 1998) and academic research (see "The legal and ethical problems of MLMs and existing measures to deal with them" Section) have described that socialization plays a relevant and potentially problematic role at MLMs. One might even argue that the strong form of socialization observed in some organizations (Bromley 1998; Groß 2008; Pratt 2000a) can be understood as a form of clan control (Ouchi 1980), as MLMs employ 'a variety of social mechanisms ... to produce a strong sense of community' (p. 136). Finally, based on the theory on the normalization of corruption (Ashforth and Anand 2003; Ashforth et al. 2008), it becomes clear that coordination by means of training and socialization can also lead to highly problematic organizational behavior. For instance, the idea of the 'social cocoon' (Greil and Rudy 1984, in Ashforth and Anand 2008; see also Jackall 1988) explains how new members 
are socialized into showing corruptive behavior, which is comparable to what happens at some highly problematic MLMs. ${ }^{1,4,10}$

Although several authors analyze how socialization takes place at MLMs (see "The legal and ethical problems of MLMs and existing measures to deal with them" Section, 'Total institutions'; i.e., Biggart 1989; Bone 2006; Cahn 2006; Friedner 2014, 2015; Groß 2008; Krige 2012; Lan 2002; Pratt 2000a,b), we still know little about how socialization that leads to ethically problematic behavior and who is responsible for it. In the next section, we will explain that the responsibility for socialization lies with what we call the distributor network (DN). This DN is a specific MLM constituent. Extending the prevailing MLM model with this constituent, we argue, will help us to better understand (the persistence) of legal and ethical problems.

\section{An Extended Model of MLMs}

The main organization as described above (see Fig. 1) helps to understand coordination efforts by headquarters. However, training and socialization at MLMs are often carried out by independent high-level distributors. As Juth-Gavasso (1985) in her analysis on Amway points out, distributors' behavior is very strongly influenced by what she calls 'training organizations.' These training organizations are run by independent high-level distributors who organize regular meetings and provide motivational material (books, videos, income charts, etc.). The training organizations include distributors that number anywhere from several 100-1000 or even 10,000 . The task of the training organizations is to teach (new) distributors the ropes of the business. In addition, and here we go beyond Juth-Gavasso (1985), distributors are socialized within the upline and downline system of MLMs. In MLMs, all distributors who recruit can use the educational program of training organizations and, at the same time, offer support and education to their downline themselves. Typical activities between upline and downline members are regular (daily) phone calls, informal meetings, and upline members accompanying their new downline to recruitment interviews or product sales (Andrews 2001; Scheibeler 2004; Smith 2013; Sonnabend 1998). Thus, training, motivation, education-or, to put it more generally: the socialization and indoctrination of distributors - is handled by independent training organizations as well as by upline members.

Our main extension of the 'prevailing' model of MLMs is to add the training organization and the upline and downline system (see Fig. 2). As both have the same function (i.e., socialization of members), we regard them as one constituent, which we call the 'distributor network' (DN).
At this point, it may be noted that distributors appear in two constituents of the extended model. For one, they appear as independent distributors selling company products and recruiting potential distributors. For another, they also appear as part of the DN. As such, distributors need to follow some training courses and are hence subject to a training organization, and they may play a role as trainer or even own a training organization themselves. Moreover, distributors have their own position in some upline or downline. We do not think that this is problematic for our model. What we see as different constituents include the same individual in different roles. So, the constituent 'independent distributor' includes some individual as distributor, i.e., as someone in the role of selling company products or recruiting other distributors. At the same time, the constituent 'DN' includes all individuals who also have a distributor role, but only in their role as part of the training organization (i.e., trainee or trainer) or in their role as 'managers.'

By including the DN in our extended model of MLMs, two additional relations become relevant (see Fig. 2). Relation R4 refers to the relationship between headquarters and the DN. Some headquarters, for instance, try to regulate the DNs by imposing guidelines about how distributors should be educated. Examples are guidelines for what should be taught at meetings, who should be allowed to speak, how much time should be devoted to product presentations, and how earnings should be presented by training organizations and upline members (see Groß 2008). Important to note, however, is that the DN typically is (legally) independent from headquarters.

Relation R5 refers to the relation between the DN and individual distributors, i.e., how distributors are influenced in how they act, think, and feel with respect to their business. As described above, this happens by means of organized activities such as large and small meetings, by motivational material provided by training organizations and uplines, by personal contact between upline and downline members, as well as by all kinds of spontaneous activities and forms of contact that take place when distributors meet each other in small, large, private, and more anonymous settings. This relation forges the ongoing socialization of independent distributors.

To complete the extended model, one might add the environment of MLMs (see also Fig. 2). Relevant parties in the environment for our purposes are governmental bodies, the law, and MLM associations. As we will discuss later, these parties (should) have an influence on how MLMs operate-however, we do not model these environmental parties as constituents in the operations of MLMs themselves, but rather as factors that provide a background for these operations. 


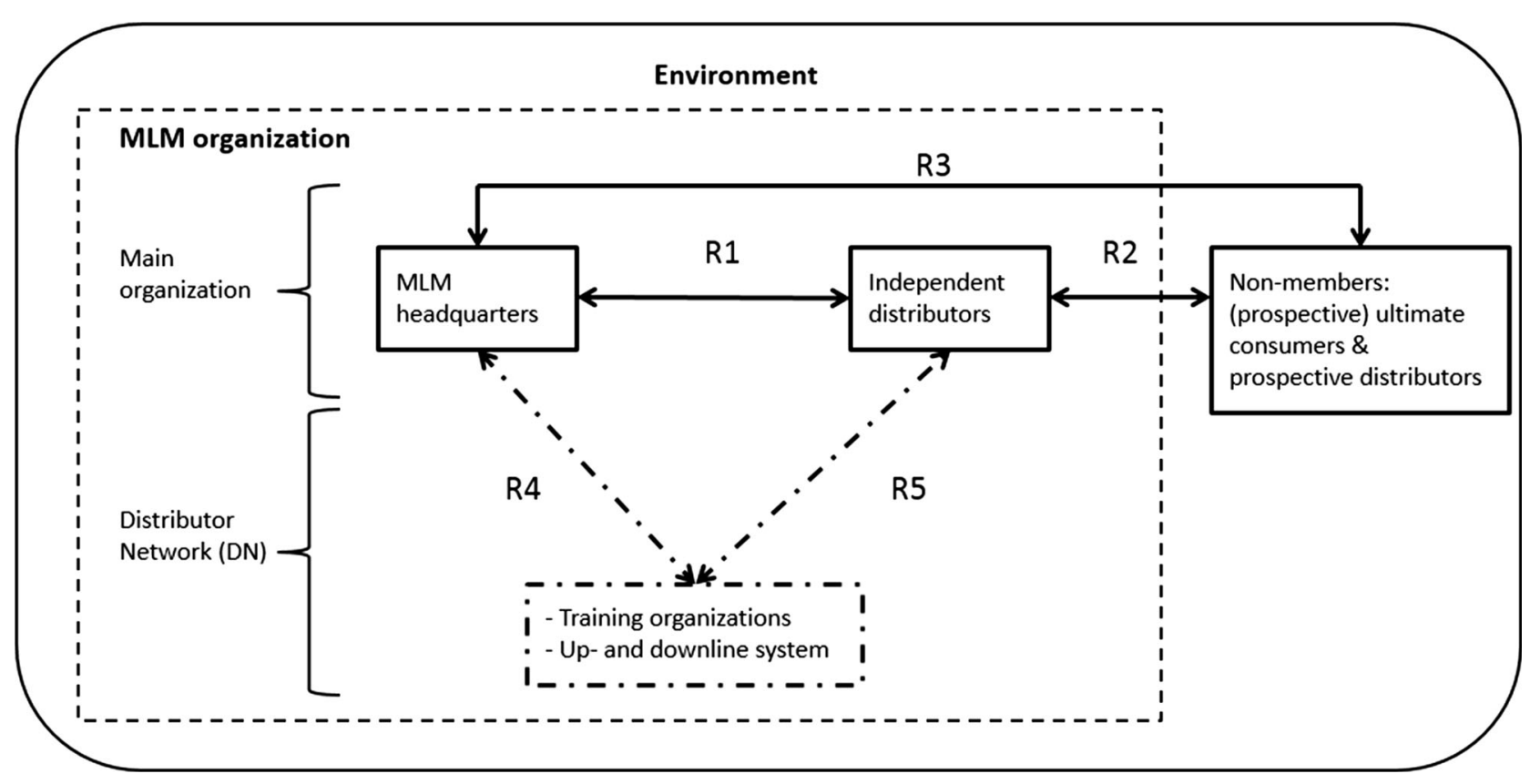

Fig. 2 Extended model of MLMs: main organization and distributor network

\section{Why Legal and Ethical Problems Persist, Despite Exiting Countermeasures}

In this section, we will use our extended model of MLMs to discuss why the legal and ethical problems persist, even though several countermeasures have been implemented to deal with these problems.

\section{Illegal Pyramid Schemes}

As discussed in "The legal and ethical problems of MLMs and existing measures to deal with them" Section, several measures have been introduced to ensure that MLMs do not operate as illegal pyramid schemes. Pyramid schemes are characterized by high (upfront) investments, inventory loading, and a business strategy focusing on recruitment (Juth-Gavasso 1985; Keep and Vander Nat 2014; Koehn 2001; Vander Nat and Keep 2002; Walsh 1999b). To solve the unsustainability produced by geometrical progression in pyramid schemes, some MLM companies restrict the amount of downline levels for which individual distributors receive override commissions. In contrast to some authors who regard this as a relevant countermeasure (Peterson and Albaum 2007; Sparks and Schenk 2006), we argue that this measure may not solve the problem as it does not really target the problem: restricting the amount of levels for which individual recruiters receive override commissions, does not limit or restrict the amount of levels of the whole company. It only restricts the number of downline levels for which each individual recruiter receives money; it does not prevent exponential progression on the company level.
Countermeasures directed at solving the problem of inventory loading, such as the $70 \%$ rule, the ten-customer rule or buyback policies, do not seem to prevent problems either. Distributors may still feel the pressure 'to purchase corporate products for their own consumption or to stockpile large amounts of inventory' (Koehn 2001, p. 155). The persistence of this problem is explained by rules not sufficiently being enforced and monitored by headquarters (Groß 2008; Keep and Vander Nat 2014; Taylor 2014).

Analyzing these measures against the background of our extended MLM model uncovers an additional underlying reason: the rules are all directed at the main organization. Existing countermeasures are part of the formal agreements between headquarters and distributors, i.e., they regulatemore or less successfully_relation R1 in Fig. 2. However, the way distributors behave is strongly influenced by the DN (relation R5). While headquarters might propagate a $70 \%$ rule, can boast a ten-customer rule, or officially represent the company as product-oriented (and not recruitment-oriented), within the network of independent distributors, a different message might be conveyed. The comparison of Amway and Mary Kay Germany (Groß 2008) illustrates this point. Although both companies emphasize the relevance of product sales in their official documents $^{24}$, the training organizations and upline members convey a different message. At local Mary Kay meetings, distributors applaud each other for recruiting as well as for product sales. At the local Amway meetings, only recruiting is honored by applause. Whereas at Mary Kay meetings recruitment is presented as an extra to one's 
sales business, at Amway, recruiting is seen as the first and foremost way to build up one's business (see also Groß and Jung 2009). Whereas at Mary Kay, distributors are invited to ask enthusiastic Mary Kay clients whether they want to join the company as distributors (Groß 2008), at Amway, the training organization recommends distributors to try to recruit others. Only when it becomes apparent that someone cannot be recruited, are distributors recommended to try to sell products to this person [see documents of the training organization provided by Rampelotto and Schwarz (1999), Schwarz and Schwarz (1993, 2001, 2002)]. Such differences between Amway headquarters' rules and the lived practices promoted by the DN illustrate that regulating the main organization of MLMs may not be enough to prevent the legally and ethically problematic focus on recruiting. A DN might overrule the countermeasures taken by headquarters. The same holds for the amount of products (new) distributors buy and stockpile. Whereas official company documents do neither ask for inventory loading nor require high investments in motivational material, during meetings organized by the DN, both might be promoted (Groß 2008). To better prevent misbehavior, we argue that it is relevant to not only regulate headquarters' activities but also the DN and its relation with individual distributors. ${ }^{16}$

\section{Misrepresenting the Business Opportunity}

Although Industry Codes of Ethics (Seldia 2011, p. 11, 12, 14; WFDSA 2008, p. 11), in line with governmental regulations, demand that their member companies do not misrepresent income opportunities, empirical evidence mounts that distributors overstate the income possibilities of their company. As Koehn (2001, p. 160) points out, the 'internet is littered with letters from disillusioned souls who report that the MLM they joined did not abide by its own rules' (see also Ramirez 2016). ${ }^{12,13,15}$ Industry watchdogs have criticized that only a few companies provide relevant and correct figures on income and/or market opportunities, often in a manner that is either incomplete or difficult to understand. ${ }^{17}$ So, one may argue that existing regulations (and/or their enforcement) are just not good enough yet. The suggested rules or codes of ethics do not urge MLMs headquarters enough to be transparent, and deliver up-to-date, relevant, concrete, and easy-to-understand figures (for the FTC's aim to change this, see Ramirez 2016; see also Pareja 2008).

Based on our extended MLM model, we want to supplement this explanation for why rules fall short. Existing rules seek to regulate the relation between headquarters and distributors (R1 in Fig. 2). As research has illustrated, however, the circumstances under which distributors sell products and recruit others are heavily influenced by the
DN, relation R5. Research (Friedner 2015; Groß 2008, 2010) and reports by former distributors (Andrews 2001; Scheibeler 2004) illustrate how the DN motivates distributors to sell and recruit. Training organizations and single upline members organize meetings and spread motivational material among distributors, showing success stories and a (seemingly) unlimited earning potential. In contrast, actual attrition rates, average earnings, and the costs of selling and recruiting are not discussed. A simple reason for that might be that headquarters does not make such figures available. Instead, distributors are motivated by stories of individuals who 'have made it.' If actual (average) income figures are provided by headquarters, they are sometimes replaced by income charts displaying potential earnings, such as five-figure incomes achieved part-time (see for example the case of Amway Germany, Rampelotto 1999; Schwarz and Schwarz 2001, 2002). ${ }^{4}$ Thus, though headquarters may have set up rules against earning misrepresentations (and thus seek to regulate relation 1 in Fig. 2), DNs' educational and motivational activities (relation 5) do not seem to be well regulated yet-neither by headquarters, industry associations nor governments (see for FTC future ideas how to change this Ramirez 2016; see also Herbalife settlement ${ }^{1}$ ).

\section{Harming Customers}

Whereas national consumer protection laws ${ }^{19}$ and Industry Codes of Ethics (DSE 2015, pp. 10-11; Seldia 2011, p. 8; WFDSA 2008, p. 7) regulate important aspects such as uncovered health claims, existing rules have not prevented MLMs from harming (external and internal) customers by providing misleading product information and (health) professionals exploiting their social status (Koehn 2001). ${ }^{29}$

We argue, again, that existing rules refer to the relation between headquarters and distributors (R1) to regulate distributors' relations toward clients and prospective distributors (R2). These two relations belong to the main organization. When analyzing existing criticism on the topic, however, it becomes clear that the DNs overrule existing measures. In companies that market nutritional supplements, for example, meetings are used to motivate distributors to make personal statements about how products cured their health problems. ${ }^{25}$ The DN thus amplifies the risk of distributors to-willingly or unwillingly-misrepresent products. At meetings, organized by the DN, laymen selling knowledge-intensive products are 'naturalized' and reinforced by such socialization practices (cf. Ashforth and Anand 2003). Confessional stories about being cured by a nutritional supplement are applauded (Biggart 1989; Groß 2008) —also by managers as current cases illustrate. ${ }^{14,16,25}$ In addition, the personal use of products is labeled as 'making consumers experts,' 
suggesting that their own consumption-based experience can replace independent, professional training (Groß 2008).

Discussing the existing countermeasures based on our extended MLM model thus suggests that some DNs might ignore existing rules while using socialization methods that create unethical behavior. As it is MLMs' core message and profit formula that 'everyone can join,' MLMs use laymen to sell their products. This makes MLMs vulnerable to harming consumers (Koehn 2001). Although MLMs do provide training courses on their specific products, we argue that such training courses are insufficient for two reasons. First, weekly, non-obligatory in-house training courses do not compare to company-independent, certified professional education. Second, as long as headquarters is not explicitly held accountable for how DNs actually train (and motivate) distributors, the problems caused by laymen giving advice are difficult to solve. Restricting membership of MLMs to people with sufficient knowledge, however, would negatively affect the profit formula of MLMs. In addition, when health (or other) professionals act as distributors, they may be prone to misusing their social status for profit reasons. This is the second dimension of how customers are potentially harmed as discussed above. Here, we argue again that as long as DNs (are allowed to) ignore the problem of professionals taking advantage of their social status, countermeasures remain insufficient.

To summarize, existing rules against the misrepresentation of products regulate how distributors should behave toward customers (relation R2 in Fig. 2). They are not, however, enforced adequately nor do they tackle relevant sources that nurture misbehavior. These sources are: the recruitment of distributors without any preselection (relation $\mathrm{R} 1$ ), the teaching and socialization of distributors by the DN (relation R5), and the subsequent lack of control of the actual practices of the DN by headquarters (relation R4).

\section{(Mis-)using Trust in Private Social Relations}

As discussed in Sect. 2, it is a widespread practice of MLMs to ask new members to first contact their 'warm market' for selling and recruiting. This is ethically sensitive as explained earlier, including the risk of distributors misusing trust and restricting the autonomy of consumers (relation R2 in Fig. 2). Countermeasures such as inventory buyback rules and withdrawal periods (Seldia 2011, p. 25; WFDSA 2008, p. 8), however, regulate the relation between headquarters and non-members (relation R3 in Fig. 2). They do not tackle or regulate the source of ethical sensitivity, i.e., the use of private social relations for economic purposes.

Some industry Codes of Conduct seek to explicitly regulate how distributors approach non-members. The European Direct Selling Association Seldia, for example, asks members to respect individuals' privacy and 'not [to] abuse the trust of individual consumers' (Seldia 2011, p. 13; see also WFDSA 2008). The problem, however, is that some DNs explicitly teach their distributors the clear expectation that friends and family members should help (new) distributors with their business (see research Bloch 1996; Juth-Gavasso 1985; Friedner 2015), and former distributors (Butterfield 1985; Smith 2013). In some companies, distributors are even taught that those who are not willing to share their dream are no true friends and therefore should be dropped (Butterfield 1985; Groß 2008; Scheibeler 2004; Smith 2013; Sonnabend 1998). In these cases, the DN not only overrules existing Codes of Ethics but also nurtures ethically problematic behavior by suggesting abandoning friends for their 'lack of friendship and help.'

\section{Total Institutions: Colonizing Every Aspect of Members' Lives}

Some MLMs have been criticized for their particular and strong organizational cultures, their strong socialization of members, and how they present themselves as means for personal and societal salvation (Bromley 1998; Cahn 2006; Groß 2010; Krige 2012; Pratt and Rosa 2003). ${ }^{21,22}$ From our point of view, the risk of MLMs acting as total institutions mainly lies in how the DN educates, socializes, and motivates (indoctrinates) distributors (relation R5 in Fig. 2).

To see how the DN contributes to this risk, it is relevant to understand that this DN can be seen as a form of (normative) control. MLM companies allow and incentivize existing distributors to (a) recruit new distributors and (b) teach and educate them. Whoever recruits new members into an MLM thus becomes a 'manager' who is responsible for the output and behavior of 'his' or 'her' recruits. By recruiting, 'normal' distributors become part of the DN that educates and trains others (relation R5). Whereas managers in most non-MLMs can motivate their employees by rights and duties regulated in an employment contract, MLM distributor-managers have no such means (see Biggart 1989). In general, they lack the rational-legal authority to make their recruits obey, as described by Weber (1980). It may be, then, that in this particular situation, MLM distributor-managers employ alternative forms of exercising power. These include strong product ideologies (Biggart 1989), strong organizational cultures, strong socialization, and all-encompassing promises (='total institutions'; see Bromley 1998; Groß 2008; Pratt 2000a). Distributor-managers might thus employ (not necessarily deliberately) the DN as a means to exercise control, potentially overruling Codes of Ethics set up by headquarters. 


\section{Summary of why Legal and Ethical Problems Persist, Despite Existing Countermeasures}

To solve and mitigate the legal and ethical problems at the MLM industry, a broad range of countermeasures by organizations, industry associations, and governments have been introduced. The ongoing problems and scandals of the industry illustrate that these do not suffice yet (see Appendix for sources). This can be explained by existing countermeasures not being enforced well enough yet (Groß 2008; Keep and Vander Nat 2014; Taylor 2014). Based on our analysis of problems against the background of our extended MLM model, we add the role of the DN to this discussion. We argue that a central reason for why problems persist is the way the $\mathrm{DN}$ is allowed to operate. Table 2 provides an overview of how the DN contributes to the persistence of problems.

A first aspect is that DNs might overrule headquarters' rules. Although headquarters might provide rules, for example against earnings misrepresentations or rules to foster product orientation and to protect the privacy of consumers and distributors, the socialization by DNs might overrule these regulations. This means that setting up rules or regulations (by headquarters or other institutions) is futile as long as these rules either not affect or are allowed to be ignored by the DN.

A second aspect is that by their teaching and socialization, DNs might amplify problems inherent in the business model. The potential risk of an MLM being recruitment-focused is connected to distributors being incentivized and motivated to recruit. Likewise, the potential harm to customers is part of MLMs' strategy to (1) allow everyone to join while most distributors lack the relevant knowledge about the MLM product they recommend or (2) allowing (health or financial) professionals to join, who might misuse their social status. Also, the potential misuse of one's 'warm market' is built into the business model if new distributors are not provided with a customer base by the company. And, finally, the risk of exploiting individuals' material and spiritual needs to

Table 2 Overview reasons for the persistence of problems despite countermeasures

\begin{tabular}{|c|c|c|c|}
\hline \multirow[t]{2}{*}{ Problem category } & \multirow[t]{2}{*}{ Dimensions } & \multicolumn{2}{|l|}{ Reasons why problems persist despite existing countermeasures } \\
\hline & & Distributor network (DN) & Headquarters (HQ) \\
\hline $\begin{array}{l}\text { 1. Illegal pyramid } \\
\text { schemes }\end{array}$ & $\begin{array}{l}\text { Focus on recruitment instead of on } \\
\text { product sales } \\
\text { Substantial upfront fees } \\
\text { Inventory loading }\end{array}$ & $\begin{array}{l}\text { Overrules HQ rules, for example by recommending } \\
\text { intensive spending on products and trainings while HQ } \\
\text { asks for low upfront fees } \\
\text { Amplifies the problem inherent to recruiting/MLM } \\
\text { companies, for example by focusing on recruitment in } \\
\text { teachings and trainings }\end{array}$ & $\begin{array}{l}\text { Little control of DN } \\
\text { enables HQ to dodge } \\
\text { responsibility }\end{array}$ \\
\hline $\begin{array}{l}\text { 2. Misrepresenting } \\
\text { the business }\end{array}$ & $\begin{array}{l}\text { Earnings misrepresentations } \\
\text { Misrepresentation of selling and } \\
\text { recruitment potential }\end{array}$ & $\begin{array}{l}\text { Overrules HQ rules, for example by emphasizing income } \\
\text { opportunities instead of presenting actual information } \\
\text { Amplifies the problem, for example by emphasizing ease } \\
\text { of success instead of providing a balanced presentation of } \\
\text { costs, efforts and income opportunity }\end{array}$ & $\begin{array}{l}\text { Reluctance to provide } \\
\text { relevant information } \\
\text { Little control of DN } \\
\text { enables HQ to dodge } \\
\text { responsibility }\end{array}$ \\
\hline $\begin{array}{l}\text { 3. Harming } \\
\text { customers }\end{array}$ & $\begin{array}{l}\text { Providing misleading product } \\
\text { information to (internal and } \\
\text { external) consumers } \\
\text { Product sales by laymen } \\
\text { Exploiting the professional-client } \\
\text { relationship }\end{array}$ & $\begin{array}{l}\text { Overrules HQ rules, for example by spreading and } \\
\text { teaching illegal health claims } \\
\text { Amplifies problem inherent to business model, i.e., lacking } \\
\text { selection of distributors by HQ, for example by } \\
\text { 'naturalizing' sales by laymen, the exploitation of } \\
\text { professional-client relationships, and unethical selling } \\
\text { practices }\end{array}$ & $\begin{array}{l}\text { Little control of DN } \\
\text { enables HQ to dodge } \\
\text { responsibility }\end{array}$ \\
\hline $\begin{array}{l}\text { 4. (Mis-)using trust } \\
\text { in private social } \\
\text { relations }\end{array}$ & $\begin{array}{l}\text { Instrumentalization of private } \\
\text { social relations }\end{array}$ & $\begin{array}{l}\text { Overrules HQ rules, for example by teaching how to best } \\
\text { make use of private relationships } \\
\text { Amplifies problem in business model, i.e., the use of warm } \\
\text { market, for example by teaching that distributors should } \\
\text { drop 'unsupportive' friends and family members }\end{array}$ & $\begin{array}{l}\text { Little control of DN } \\
\text { enables to dodge } \\
\text { responsibility }\end{array}$ \\
\hline 5. Total institutions & $\begin{array}{l}\text { Socialization along company } \\
\text { beliefs } \\
\text { Intrumentalization of spiritual } \\
\text { needs for economic purposes }\end{array}$ & $\begin{array}{l}\text { Overrules HQ rules (if existent) and amplifies problem } \\
\text { inherent in lacking formal authority, for example by } \\
\text { elevating the recruitment of others and the sale of } \\
\text { consumer products to a cure-all for problems of modern } \\
\text { society }\end{array}$ & $\begin{array}{l}\text { Little control of DN } \\
\text { enables HQ to dodge } \\
\text { responsibility }\end{array}$ \\
\hline
\end{tabular}


motivate one's downline is fueled by recruiters lacking other means to make their downline obey. Whereas headquarters could use the training courses of their distributors to mitigate the described problems, for example by teaching and enforcing already existing Codes of Ethics, the above-quoted empirical evidence suggests that DNs' teaching and socialization techniques might reinforce unethical behavior. In the case of problematic MLM behavior, DNs' processes of socialization can thus, in fact, be regarded as an instantiation of the practices normalizing corruption (Ashforth and Anand 2003).

A third aspect is that by headquarters portraying and treating DNs as independent entities, headquarters are better able to sidestep criticism. As Juth-Gavasso (1985) already suggested in her analysis on Amway, the legal independence of distributors, uplines, and training organizations can be used as an excuse for headquarters to tolerate and dodge responsibility for practices that are illegal and unethical but stimulate product sales and recruitment (for current cases see LifePlus Germany and Herbalife India ${ }^{11}$ ). As long as headquarters does not (formally) exercise sufficient control over the actual behavior and business practices of the DN, headquarters is better able to put the blame for misbehavior on the independent distributors, manager-distributors, and training organizations. This includes dodging responsibility and accountability for the non-compliance with rules headquarters has set up itself.

\section{Reflecting on Additional Countermeasures}

Dealing with the persistent legal and ethical problems is a central issue for consumers, (prospective) distributors, MLMs, and regulators alike. In the previous sections, we argued that one reason for the persisting problems is that the implemented countermeasures fail to take the DN into account. In this section, we will briefly consider other countermeasures than those that have already been implemented. That is, we evaluate some alternative proposals (which have not been implemented yet) and we propose some countermeasures ourselves. Our main suggestion for evaluating these countermeasures is that whatever set of measures is chosen, some of them should be explicitly directed at the role of DNs in how MLMs (are allowed to) operate.

A first set of suggested additional measures concerns specifying and better enforcing existing rules and regulations. Keep and Vander Nat (2014) and Bosley and McKeage (2015) suggest, for example, that MLMs should be asked to provide more verifiable data on sales to ultimate consumers (see also Pareja 2008). This would make it considerably easier for regulators to distinguish a legitimate MLM system from a pyramid scheme (Bosley and McKeage 2015; Pareja 2008). In addition, income disclosures and 'disclosures of the probability of success' should become generally available to increase the transparency of the industry (Ramirez 2016). ${ }^{26}$ Based on our analysis of problems, we fully agree with these suggestions. We think that MLMs should be obliged by governments to provide key performance figures, such as income opportunities, income likelihood, attrition rate, and average earnings. Based on our extended MLM model, we think it is necessary to complement such regulations with an additional measure: holding DNs accountable for (a) communicating these figures and (b) prohibiting the use of any other, 'alternative' figures. Groß (2008) observed, for example, that whereas Amway's German headquarters made no exaggerated income claims, the associated, independent European training organization Max Schwarz did. Thus, based on our model, asking headquarters to provide more transparency is very relevant. It will, however, be more effective, when, in addition, DNs are held accountable for exclusively using these official figures (see the FTC's settlement with Herbalife ${ }^{1}$ and its view on transparency, Ramirez 2016).

A second set of recommendations is directed at improving consumer education. For the US context, Bosley and McKeage (2015) suggest increasing consumer literacy, for example by increasing consumer education in secondary schools, in particular financial literacy. In addition, for the particular case of illegal pyramid schemes, the authors suggest providing fraud detection training to statelevel investigators. While we agree with the need for better consumer education, we still regard a better regulation of the DN as a relevant way of preventing problems to occur.

A third set of suggestions focuses on changing how MLMs are actually allowed to operate, i.e., changing the very business model. FitzPatrick (n.d.), for example, suggests prohibiting recruitment by existing distributors ${ }^{6}$, which would solve the pyramid issue as well as take away distributors' interest in misrepresenting the business opportunity to others. Hyman (2009) suggests to combine a reduction of distributor levels (Peterson and Albaum 2007; Sparks and Schenk 2006) with a more equitable distribution of income between upline and downline levels (Hyman 2007). ${ }^{27}$ Such an approach would make MLMs automatically behave more ethically, as exaggerated income promises might be deflated and more people might earn a more appropriate share of income. Hyman (2007, 2009) suggests ensuring that MLMs communicate honestly about what MLMs actually are, i.e., buying-clubs instead of 'get-rich-quickly' schemes. In addition, internal consumption should be (better) regulated, i.e., regulatory agencies should define the share of products that needs to be sold to ultimate customers-such as the FTC did for 
Herbalife (see settlement). ${ }^{1}$ This way, it would be possible to distinguish MLMs that are legal retail companies from recruiting-oriented pyramid schemes (Pareja 2008; TokajiNagy 2016). ${ }^{6}$

Based on our analysis of problems, we think that all of the above measures are highly relevant. However, we would argue that these measures alone may either be unfeasible or by themselves prove insufficient. Indeed, we would argue to complement such measures with approaches that explicitly regulate how DNs operate.

Prohibiting recruitment may, for instance, simply not be a politically feasible option at the moment (Tokaji-Nagy 2016). ${ }^{7}$ If one cannot abolish (pseudo-)pyramid schemes like MLMs and if current legislation is unable to reduce the problems caused by it, an alternative approach might include measures explicitly dealing with how DNs are allowed to operate.

Also asking MLMs to communicate honestly about their business proposition (Hyman 2007, 2009) will not solve all problems. As long as the DNs operate independently, they can still play their part in indoctrination and socialization of distributors, causing the ethical problems as we have described. An independent DN may still 'overrule' headquarters' honesty, for example by inflated promises about income, product quality, and working conditions (see FTC's view on this topic, Ramirez 2016).

In addition, if the income of high level distributors were reduced by restricting the number of layers (Hyman 2007; Peterson and Albaum 2007; Sparks and Schenk 2006) in combination with redistributing income between upline and downline levels more equally (Hyman 2007), it might even be expected that the DN would operate in a more aggressive way to overcome this loss. We also want to point out that the costs distributors make partially derive from DNs as they charge costs for training courses, seminars, rallies, and motivational material. As long as DNs operate independently from headquarters, costs of running an MLM business may still exceed most distributors' income-even after redistributing income more equally between uplines and downlines.

From our perspective, then, as long as independent training organizations earn money from the turnover (internal or external) of other distributors, they may remain incentivized to socialize distributors to hard sell, misrepresent the business opportunity, and attract customers with problematic product claims. ${ }^{5}$ Even if distributors were only recruited via headquarters, the risk of 'educating' distributors in ethically problematic practices would remain as long as those who provide this 'education' earn money from doing so. One way of dealing with this is to ensure that training and education are completely organized by headquarters (see Herbalife settlement for obligatory training courses ${ }^{1}$ ), which in turn is held accountable for its practices - as already stated in the industry's codes of ethics (Ramirez 2016). Alternatively, DNs should be explicitly held accountable for what they do.

To summarize, given the influence of the DN on (mis)behavior in the MLM industry, we think that it is central to oblige headquarters to provide correct, understandable, and appropriate data (for exemplary presentations by $\mathrm{Nu}$ Skin Europe and Herbalife in Europe ${ }^{30}$ ) and to better educate consumers about the MLM industry. Aside from these measures, we regard it as important to regulate the relations between the main organization and the DN (relations R4 and R5). Here, we suggest holding headquarters (more) accountable for the actual practices of their DN as the current situation does not urge headquarters enough to do something about misbehavior (see how the FTC acknowledges and plans to tackle this problem, Ramirez $2016^{28}$ ). Moreover, headquarters could reduce the discretion of DNs by defining the content of training courses, offering training courses themselves (see for example the education initiative by Amway's headquarters ${ }^{31}$ ), and influencing the nature of the company values that are propagated during meetings (see for example how Tupperware exercises far stronger control over its training organizations than Amway; Groß 2008). In fact, the more headquarters is formally responsible for DNs' activities (and hence, the less independent the DN), the more it can be held responsible for misbehavior. Asking MLM headquarters to take such formal and legal responsibility should become part of governmental regulation of MLMs (see Herbalife settlement ${ }^{1}$ and Ramirez 2016). Such regulations could entail making it obligatory for MLMs to educate their own distributors or to organize their own motivational meetings (or to prohibit outsourcing them). In addition, we suggest thinking about rules for holding training organizations and uplines accountable for what is propagated during training courses, meetings, and in educational material. Here, rules and legislation could be strengthened on industry or national governmental level.

So, what we propose here is to hold DNs responsible and accountable for their behavior. This can be achieved by (a) urging headquarters to exercise more control; (b) by making current activities of the DN the explicit (legal) responsibility of headquarters; and/or (c) by making sure that regulations are also directed at parts of the DN.

Although we regard existing countermeasures, measures suggested by other authors, and measures suggested by us as relevant, we want to end this section by saying that we doubt that all problems can really be solved. The reason is that many of them seem to be part of the very business model of MLMs (see also Hyman 2007, 2009; Koehn 2001, for a similar observation): as long as recruitment is part of the business model, the danger of illegal pyramid schemes lures. In addition, if one is trapped into such a scheme, the 
only way to attract others may be to misrepresent the business. As long as the business model revolves around attracting basically anyone as distributor or as member of a buying club, the danger of distributors harming customers by keeping them in the dark is real. As long as the business model is built around independent distributors without a client base provided by the company, the danger of misusing trust in private social relations exists, even if income promises are deflated. Finally, as long as MLM distributormanagers lack any legal-rational authority over 'their' downline members or 'buying clubs,' the risk that distributor-managers use and misuse their downlines' economic, emotional, and spiritual needs to motivate and guide them, is hard to prevent.

In conclusion, as long as MLMs are allowed to operate as they do, their business model is prone to causing legal and ethical problems. Thus, we suggest that it is relevant to combine a broad range of countermeasures, including measures directed at regulating the DNs.

\section{Conclusion}

With its impressive growth throughout the last decades (WFDSA 2016), the MLM industry has proven an important player in the distribution of goods and services and a popular retail channel. The focus of this paper, however, was on the problematic side of the industry as we set out to (a) explicate the role of the DN in the persistence of legal and ethical problems and (b) discuss potential, but limited, measures to deal with these problems.

To reach this goal, we provided an extended MLM model in "Understanding how MLMs operate: a 'prevailing' and an 'extended' model" Section. To present this extended model, we first explicated the implicit 'prevailing MLM model,' consisting of headquarters, independent distributors, and (prospective) clients and distributors. Next, we extended this prevailing model with an extra constituent: the 'distributor network' (DN). While we are not the first authors to write about the legal and ethical problems of MLMs nor the first to discuss how distributors are socialized, our analysis extends existing research in the following ways. First, in order to provide an appropriate starting point for our analysis, in "The legal and ethical problems of MLMs and existing measures to deal with them" Section we provide an overview, including the legal and ethical problems of MLMs and existing countermeasures. Second, although existing research analyzes how upline members recruit and socialize 'their' downline (Biggart 1989; Pratt 2000a, b), we also explicate how these practices are linked to problematic behavior displayed by some MLMs. Third, whereas Juth-Gavasso (1985) pointed out the relevance of Amway's training organizations for legally problematic behavior, we extended her ideas by (a) including the upline and downline system into the DN; (b) using our extended model to analyze not only legal but also (other) ethical problems; and (c) going beyond a single company to reflect on the specific constituents of MLMs. Fourth, explicating the MLM constituents and the relations between them allowed us to provide a better understanding of why problems persist and existing countermeasures do not suffice. Finally, using our extended model, we discussed potential additional countermeasures in "Reflecting on additional countermeasures" Section.

The MLM model presented in our paper thus provides a background for diagnosing current legal and ethical problems of MLMs, evaluating the effect of current countermeasures, and designing new measures to mitigate legal and ethical problems. However, the actual use of our model requires further research. In particular, a more detailed company and country-specific analysis of how education, training, and socialization take place (see for example Groß 2008; Juth-Gavasso 1985; Lan 2002; Pratt 2000a, b) might provide deeper insights into the nature of the problematic DN-micro-practices and how they may be prevented. It is, for example, highly relevant to research the industry's 'best practices.' How do MLM companies who work in a morally sound way deal with and regulate their DN? Which measures are taken by those headquarters to successfully mitigate the above described risks? Which organizational 'best practices' exist that might be introduced on a larger scale? What is more, as legislation and MLM practices differ from country to country, further research into both countermeasures, and country-specific legal and ethical issues is needed.

Research into the role of DNs as a source of unethical behavior in MLMs may also benefit from (and be relevant for) research into the normalization of corruption (Ashforth and Anand 2003; Ashforth et al. 2008; Nelson 2016). This might prove to be worthwhile in order to understand the role of DNs in terms of the processes involved in normalizing corruption (e.g., institutionalization, rationalization and socialization, Ashforth and Anand 2003). At the same time, analyzing highly problematic MLMs might also provide new insights into how the normalization of corruption takes place, while studying unproblematic MLM companies might help understanding what needs to be done to prevent such behavior.

In addition, whereas our article focuses on the problematic aspects of the MLM industry, a far broader underlying topic of our analysis is how organizations aredeliberately or not—designed to avoid, ignore, or disclaim accountability. As research on the interplay of formal and informal organizational systems has shown (Smith-Crowe et al. 2015), employees can be directed to show ethical behavior by formal systems (i.e., ethics programs), whereas 
informal systems, such as unwritten norms and conventions, may foster fraudulent behavior. Although the independence of DNs in MLMs is a very particular case, it illustrates and might further contribute to the discussion on how organizations can be designed to lower the risk of formal programs that are contrary to informal norms (Smith-Crowe et al. 2015) or decoupled from actual practices (Clegg and Gordon 2012; Jackall 1988; MacLean et al. 2015).

Moreover, it can be argued that a better understanding of the way 'good' and 'bad' practice MLMs operate is relevant, because MLMs are part of the growing non-traditional forms of employment in Western countries, such as freelancing, subcontracting, and franchising (Kalleberg 2009). These forms share central characteristics, including precarious working conditions for the self-employed, selfemployed working from a distance, employers being exempted from social security contributions, and remuneration being bound to financial performance criteria. Thus, insights provided in this article could cross-fertilize the understanding of similar forms of employment. In particular, it is interesting to ask how the outsourcing of central business activities (in our case: selling company products and hiring new 'employees') might be connected with the 'outsourcing' of headquarters' responsibility for (un-)ethical behavior.

\section{Compliance with Ethical Standards}

Conflict of interest The authors declare that they have no conflict of interest.

Ethical Approval This article does not contain any studies with human participants or animals performed by any of the authors.

Open Access This article is distributed under the terms of the Creative Commons Attribution 4.0 International License (http://crea tivecommons.org/licenses/by/4.0/), which permits unrestricted use, distribution, and reproduction in any medium, provided you give appropriate credit to the original author(s) and the source, provide a link to the Creative Commons license, and indicate if changes were made.

\section{Appendix}

See Table 3.

Table 3 Additional (other than academic) sources on MLMs

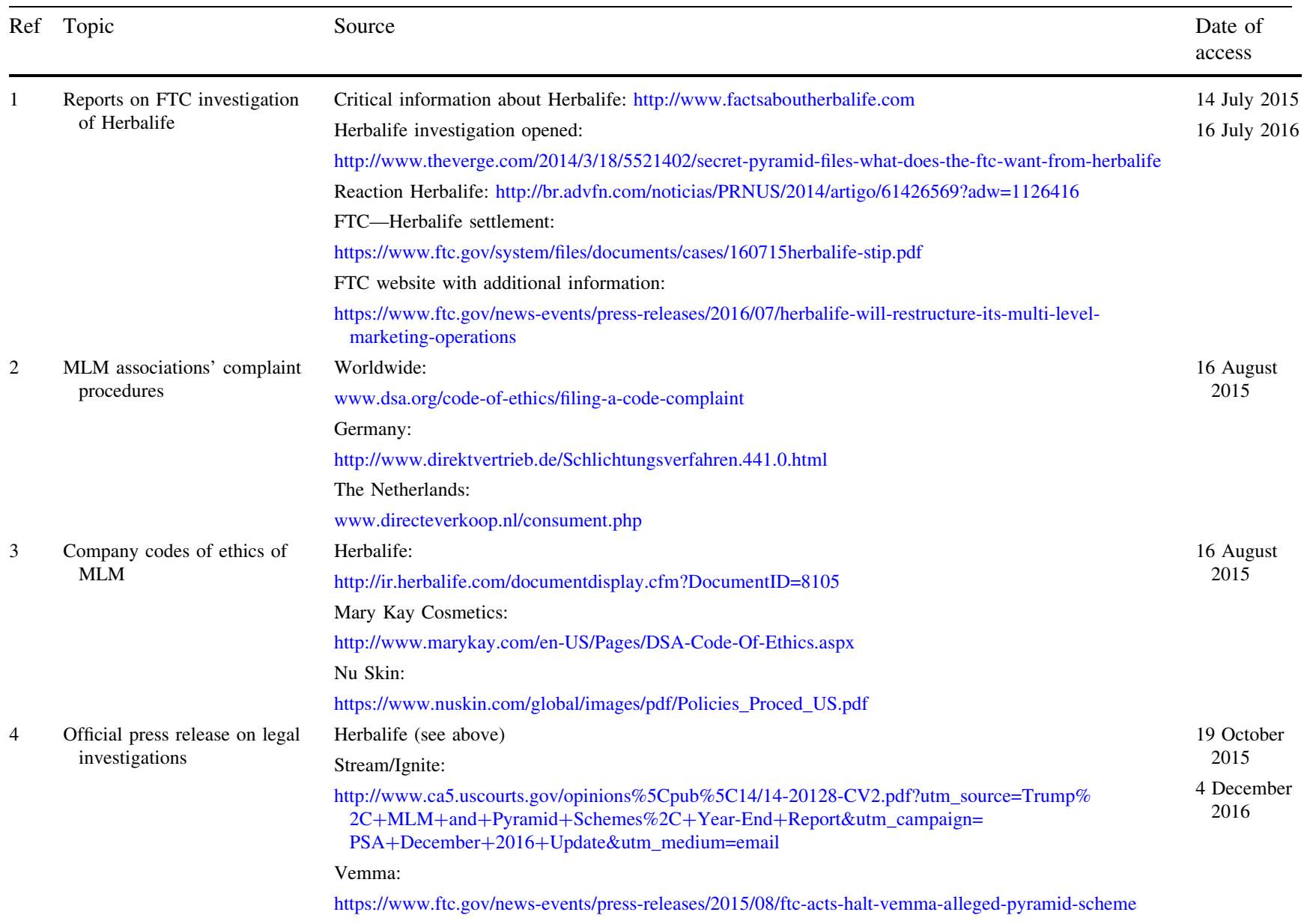


Table 3 continued

\begin{tabular}{|c|c|c|c|}
\hline Ref & Topic & Source & $\begin{array}{l}\text { Date of } \\
\text { access }\end{array}$ \\
\hline 5 & $\begin{array}{l}\text { Consumer advocates reporting } \\
\text { on ethical/legal problems of } \\
\text { MLMs by watchdog } \\
\text { organizations }\end{array}$ & $\begin{array}{l}\text { http://www.mlm-thetruth.com/ http://pyramidschemealert.org } \\
\text { http://www.mlmwatch.org } \\
\text { http://www.sequenceinc.com/fraudfiles/category/pyramid-schemes-mlm } \\
\text { http://mlmpetition.com/ }\end{array}$ & $\begin{array}{l}14 \text { July } 2015 \\
3 \text { March } \\
2017\end{array}$ \\
\hline 6 & $\begin{array}{l}\text { Consumer advocate suggesting } \\
\text { to forbid recruiting }\end{array}$ & $\begin{array}{l}\text { http://campaign.r20.constantcontact.com/render?ca=16c71fc7-f96f-4c2b-9d04-0e14628990be \&c= } \\
\text { fb5f6b80-36fc-11e3-83c6-d4ae528eb27b\&ch=fc329a00-36fc-11e3-84c2-d4ae528eb27b } \\
\text { http://seekingalpha.com/article/3980851-spanish-prisoner-herbalife-gets-money-ftc-can }\end{array}$ & 18 June 2016 \\
\hline 7 & $\begin{array}{l}\text { Critical review of Bill H.R. } \\
5230 \text { as legalizing illegal } \\
\text { pyramid schemes; illustrates } \\
\text { strong MLM lobby }\end{array}$ & $\begin{array}{l}\text { http://seekingalpha.com/article/3976475-disgusting-shameful-bill-h-r-5230-legalize-current-pyramid- } \\
\text { schemes } \\
\text { https://www.truthinadvertising.org/pyramid/ }\end{array}$ & 18 June 2016 \\
\hline 8 & $\begin{array}{l}\text { Media reports on MLMs/ } \\
\text { MLMs as pyramid schemes }\end{array}$ & $\begin{array}{l}\text { http://seekingalpha.com/article/3362825-herbalife-mlms-and-the-ftc-some-questions-and-a-challenge-for- } \\
\text { market-analysts-and-the-financial-press } \\
\text { http://www.bloomberg.com/news/articles/2015-02-27/an-insider-explains-why-the-ftc-can-t-put-an-end-to- } \\
\text { pyramid-schemes }\end{array}$ & $\begin{array}{l}5 \text { August } \\
2015\end{array}$ \\
\hline 9 & Governmental buyback policies & $\begin{array}{l}\text { Germany: } \\
\text { www.gesetze-im-internet.de/bgb/_355.html } \\
\text { US: } \\
\text { http://www.mlmlaw.com/law-library/guides-reference/multilevel-marketing-primer/\#7 }\end{array}$ & $\begin{array}{l}16 \text { August } \\
2015\end{array}$ \\
\hline 10 & $\begin{array}{l}\text { Media releases illustrating } \\
\text { persistence of pyramid } \\
\text { scheme practices }\end{array}$ & $\begin{array}{l}\text { Herbalife: } \\
\text { http://seekingalpha.com/article/3362825-herbalife-mlms-and-the-ftc-some-questions-and-a-challenge-for- } \\
\text { market-analysts-and-the-financial-press } \\
\text { http://www.marketfolly.com/2012/05/transcript-of-david-einhorns-questions.html } \\
\text { Vemma (official FTC press release): } \\
\text { https://www.ftc.gov/news-events/press-releases/2015/08/ftc-acts-halt-vemma-alleged-pyramid-scheme }\end{array}$ & $\begin{array}{l}7 \text { January } \\
2016\end{array}$ \\
\hline 11 & $\begin{array}{l}\text { Critical reviews on } \\
\text { headquarters' lack of } \\
\text { responsibility for DN } \\
\text { misbehavior }\end{array}$ & $\begin{array}{l}\text { LifePlus Germany: } \\
\text { https://www.youtube.com/watch?v=PA3502FiWLk } \\
\text { Herbalife India: } \\
\text { http://www.cnbc.com/2013/10/17/claims-of-herbalife-distributors-in-india-raise-questions.html }\end{array}$ & $\begin{array}{l}21 \\
\text { November } \\
2014\end{array}$ \\
\hline 12 & $\begin{array}{l}\text { Consumer advocates reporting } \\
\text { on misrepresentation of } \\
\text { business opportunities }\end{array}$ & $\begin{array}{l}\text { http://www.mlmwatch.org/01General/misrepresentations.html } \\
\text { http://www.jenman.com.au/Downloads/MythofMLMIncome.pdf } \\
\text { http://mlm-thetruth.com/research/reports/summary-key-conclusions/ }\end{array}$ & $\begin{array}{l}7 \text { January } \\
2016\end{array}$ \\
\hline 13 & $\begin{array}{l}\text { Consumer advocates reporting } \\
\text { on MLM misrepresentations }\end{array}$ & $\begin{array}{l}\text { http://www.mlm-thetruth.com } \\
\text { http://pyramidschemealert.org } \\
\text { http://www.mlmwatch.org/ } \\
\text { http://www.mlmobserver.com/ } \\
\text { http://www.sequenceinc.com/fraudfiles/category/pyramid-schemes-mlm } \\
\text { http://mlm-thetruth.com/research/reports/summary-key-conclusions/ } \\
\text { http://mlmpetition.com/ }\end{array}$ & $\begin{array}{l}7 \text { January } \\
2016 \\
12 \text { December } \\
2016 \\
3 \text { March } \\
2017\end{array}$ \\
\hline 14 & $\begin{array}{l}\text { Company examples of } \\
\text { motivational 'success stories' }\end{array}$ & $\begin{array}{l}\text { Herbalife: } \\
\text { https://www.youtube.com/watch?v=WanbFVQyEq8 } \\
\text { Lifeplus: } \\
\text { https://www.youtube.com/watch?v=OQQ4CDtvKzY } \\
\text { Mary Kay: } \\
\text { http://www.marykay.com/en-US/beabeautyconsultant/Pages/success-stories-featured-profiles.aspx }\end{array}$ & 19 May 2016 \\
\hline 15 & $\begin{array}{l}\text { Company material (Vemma) } \\
\text { illustrating how income } \\
\text { opportunities are } \\
\text { (mis)represented }\end{array}$ & $\begin{array}{l}\text { (1) Promotional video: } \\
\text { https://www.youtube.com/watch?v=3pd0cKQEtSg } \\
\text { (2) US income disclosure of Vemma 2013: } \\
\text { http://vemmanews.com/2014/03/05/vemma-2013-income-disclosure/ } \\
\text { (3) A critical interpretation of the income disclosure: http://amlmskeptic.blogspot.nl/2014/07/due- } \\
\text { diligence-how-to-read-income.htm }\end{array}$ & 15 July 2015 \\
\hline
\end{tabular}


Table 3 continued

\begin{tabular}{|c|c|c|c|}
\hline Ref & Topic & Source & $\begin{array}{l}\text { Date of } \\
\text { access }\end{array}$ \\
\hline 16 & $\begin{array}{l}\text { Media release illustrating } \\
\text { current company example } \\
\text { (Herbalife) for how official } \\
\text { rules and actual practices can } \\
\text { be decoupled }\end{array}$ & $\begin{array}{l}\text { http://seekingalpha.com/article/3740536-herbalife-is-moving-underground-with-their-business- } \\
\text { opportunity-pitch }\end{array}$ & $\begin{array}{l}3 \text { January } \\
2016\end{array}$ \\
\hline 17 & $\begin{array}{l}\text { Consumer watchdogs critical } \\
\text { reviews of actual income \& } \\
\text { official income disclosures } \\
\text { MLM }\end{array}$ & $\begin{array}{l}\text { Critical reviews of actual income: } \\
\text { http://pyramidschemealert.org } \\
\text { http://www.mlmobserver.com/ } \\
\text { http://www.mlm-thetruth.com/ } \\
\text { http://www.mlmwatch.org/ } \\
\text { http://www.sequenceinc.com/fraudfiles/category/pyramid-schemes-mlm/ } \\
\text { http://www.transgallaxys.com/ beo/umsatz/umsatz_mlm.htm } \\
\text { http://seekingalpha.com/article/3966363-herbalife-distributor-earnings-disclosure-statements?li_source= } \\
\text { LI\&li_medium=liftigniter-widget } \\
\text { http://mlmpetition.com/ } \\
\text { Income disclosures MLM companies: } \\
\text { http://pyramidschemealert.org/income-disclosures-of-herbalife-nu-skin-and-amway-2012/ } \\
\text { http://www.sequenceinc.com/fraudfiles/2012/12/multi-level-marketing-income-disclosures/ }\end{array}$ & $\begin{array}{l}1 \text { July } 2015 \\
17 \text { March } \\
2017\end{array}$ \\
\hline 18 & $\begin{array}{l}\text { Media reports on illegal } \\
\text { product claims }\end{array}$ & $\begin{array}{l}\text { http://abcnews.go.com/Blotter/caught-tape-herbalife-cures-brain-tumor/story?id=23441488\&singlePage= } \\
\text { true }\end{array}$ & 2 May 2015 \\
\hline 19 & $\begin{array}{l}\text { Governmental legislation on } \\
\text { nutritional claims }\end{array}$ & $\begin{array}{l}\text { US: } \\
\text { http://www.accessdata.fda.gov/scripts/cdrh/cfdocs/cfcfr/CFRSearch.cfm?fr=101.14 } \\
\text { Europe: } \\
\text { http://ec.europa.eu/food/safety/labelling_nutrition/claims/index_en.htm } \\
\text { http://eur-lex.europa.eu/LexUriServ/LexUriServ.do?uri=OJ:L:2005:149:0022:0039:EN:PDF }\end{array}$ & $\begin{array}{l}9 \text { August } \\
2015 \\
26 \\
\text { November } \\
2015\end{array}$ \\
\hline 20 & $\begin{array}{l}\text { Media reports on MLM } \\
\text { headquarters dodging illegal } \\
\text { product claims }\end{array}$ & $\begin{array}{l}\text { US: } \\
\text { http://abcnews.go.com/Blotter/caught-tape-herbalife-cures-brain-tumor/story?id=23441488\&singlePage= } \\
\text { true } \\
\text { Germany: } \\
\text { http://www.br.de/fernsehen/bayerisches-fernsehen/sendungen/kontrovers/stellungnahme-lifeplus-europe- } \\
\text { ltd-102.html }\end{array}$ & 2 May 2015 \\
\hline 21 & $\begin{array}{l}\text { Watchdog groups } \\
\text { characterizing MLMs as } \\
\text { (quasi-religious) cults }\end{array}$ & $\begin{array}{l}\text { http://www.falseprofits.com/files/1a752febbefe73223e22a28e5e5e5106-35.html } \\
\text { http://amlmskeptic.blogspot.nl/search/label/MLMBasics } \\
\text { https://www.youtube.com/watch?v=CApMzIX46kw } \\
\text { https://freedomofmind.com/beware-the-main-street-bubble-of-multi-level-marketing-groups-without-u-s- } \\
\text { government-protection/ } \\
\text { https://sometimesmagical.wordpress.com/2014/04/12/cult-spotting-101-breaking-down-multi-level- } \\
\text { marketing-schemes-guest-post/ }\end{array}$ & $\begin{array}{l}3 \text { March } \\
2017\end{array}$ \\
\hline 22 & $\begin{array}{l}\text { European church and state run } \\
\text { consumer protection groups } \\
\text { providing advice on MLMs } \\
\text { that are perceived as (quasi- } \\
\text { religious) cults }\end{array}$ & $\begin{array}{l}\text { http://www.bundesstelle-sektenfragen.at/ } \\
\text { http://www.confessio.de/cms/website.php?id=/religionheute/strukturvertriebe/ideologie_im_ } \\
\text { strukturvertrieb.html } \\
\text { http://www.weltanschauung.elk-wue.de/fileadmin/mediapool/einrichtungen/E_ } \\
\text { weltanschauungsbeauftragte/DoksO-T/Struktur.pdf } \\
\text { http://www.srf.ch//konsum/themen/geld/forever-living-jetzt-spricht-die-sektenexpertin } \\
\text { http://www.infosekta.ch/media/uploads/2015_Pressemitteilung_zum_Jahresbericht2014_2014_ } \\
\text { 16April2015.pdf }\end{array}$ & $\begin{array}{l}16 \text { April } \\
2015\end{array}$ \\
\hline 23 & $\begin{array}{l}\text { Independent training } \\
\text { organizations websites }\end{array}$ & $\begin{array}{l}\text { Dexter Yager (Amway US): http://www.businessforhome.org/2011/08/dexter-yager-amway-review-2011/ } \\
\text { Schwarz-Diamond-Connection (Amway EU): http://www.schwarz-organisation.eu/en/home-0 }\end{array}$ & 15 July 2015 \\
\hline 24 & $\begin{array}{l}\text { Promotional company material } \\
\text { showing the importance of } \\
\text { selling products }\end{array}$ & $\begin{array}{l}\text { Amway video 'Start a Business': http://www.amway.com/start-a-business } \\
\text { Mary Kay video 'New Beauty Consultant': http://www.marykay.com/en-US/BeABeautyConsultant/Pages/ } \\
\text { Get-Started-Starter.aspx. }\end{array}$ & 5 May 2015 \\
\hline 25 & $\begin{array}{l}\text { Distributor health claims and } \\
\text { problematic product claims }\end{array}$ & $\begin{array}{l}\text { 'Truth in advertising' database, including over } 1000 \text { problematic health claims made by } 60 \text { MLMs that sell } \\
\text { nutritional supplements and are member of the DSA (Direct Selling Association): https://www. } \\
\text { truthinadvertising.org/mlm-health-claims-database/ } \\
\text { For Herbalife see also: http://www.factsaboutherbalife.com/harmful-promises/ }\end{array}$ & $\begin{array}{l}18 \text { August } \\
2015 \\
5 \text { May } 2016\end{array}$ \\
\hline
\end{tabular}


Table 3 continued

\begin{tabular}{|c|c|c|c|}
\hline Ref & Topic & Source & $\begin{array}{l}\text { Date of } \\
\text { access }\end{array}$ \\
\hline 26 & $\begin{array}{l}\text { Consumer advocates' } \\
\text { suggestions for improving } \\
\text { MLM industry }\end{array}$ & $\begin{array}{l}\text { Obligatory income disclosures: } \\
\text { http://seekingalpha.com/article/3966363-herbalife-distributor-earnings-disclosure-statements?li_source= } \\
\text { LI\&li_medium=liftigniter-widget } \\
\text { Better enforcement of existing rules and regulations: } \\
\text { http://seekingalpha.com/article/3816976-herbalife-goodbye } \\
\text { http://seekingalpha.com/article/3815316-regulators-financial-partners-multilevel-marketing-house-cards } \\
\text { http://seekingalpha.com/article/4006010-celebrating-multilevel-marketing-model-2-fears-pr-fix }\end{array}$ & $\begin{array}{l}20 \text { June } 2016 \\
13 \\
\quad \text { September } \\
2016\end{array}$ \\
\hline 27 & $\begin{array}{l}\text { Suggestion to improve } \\
\text { distribution of income }\end{array}$ & $\begin{array}{l}\text { More equitable distribution of income between up- and downline levels: } \\
\text { http://mlm-thetruth.com/dsa-vs-consumers/ }\end{array}$ & 20 June 2016 \\
\hline 28 & $\begin{array}{l}\text { Letter of FTC Chairwoman } \\
\text { Ramirez to DSA, January 19, } \\
2017\end{array}$ & $\begin{array}{l}\text { https://www.ftc.gov/system/files/documents/public_statements/1068663/response_to_dsa_letter_ramirez. } \\
\text { pdf }\end{array}$ & $\begin{array}{l}20 \text { February } \\
2017\end{array}$ \\
\hline 29 & $\begin{array}{l}\text { Watchdog organizations } \\
\text { problematizing health } \\
\text { professionals as MLM } \\
\text { distributors }\end{array}$ & $\begin{array}{l}\text { https://www.ncahf.org/articles/j-n/mlm.html } \\
\text { http://www.ncahf.org/pp/mlm.html }\end{array}$ & $\begin{array}{l}3 \text { March } \\
2017\end{array}$ \\
\hline 30 & $\begin{array}{l}\text { Examples transparent and } \\
\text { understandable income } \\
\text { disclosures }\end{array}$ & $\begin{array}{l}\text { NuSkin for all Europe, Middle East, \& Africa Countries (2015) see here: https://www.nuskin.com/content/ } \\
\text { dam/eu-library/CompPlanExtended/DCS/distributor_compensation_summary-all-EMEA.pdf } \\
\text { Herbalife for some of its European countries, see for example } \\
\text { The Netherlands: https://edge.myherbalife.com/vmba/media/CC21DCE1-241A-4383-B286- } \\
\text { 1D9B94D16A69/Web/General/Original/SAGC_Netherlands.pdf } \\
\text { Germany: } \\
\text { https://edge.myherbalife.com/vmba/media/F1AA67FB-02D9-42B7-9388-FE8ADF87A4C9/Web/General/ } \\
\text { Original/Angabenzudendurchschnittlic } \\
\text { henBruttozahlungenfuerHERBALIFEMitgliederinDeutschland.pdf } \\
\text { UK: } \\
\text { https://edge.myherbalife.com/vmba/media/F3915EF0-F5F2-4D2A-8609-0DED9D4517B7/Web/General/ } \\
\text { Original/SAGC_UK.pdf } \\
\text { Italy: } \\
\text { http://edge.myherbalife.com/vmba/media/64DE5D8B-7D33-4E3C-BA1D-6EF84ED8E99D/Web/General/ } \\
\text { Original/Italy_SAGC_2014_050415_translatedREV.pdf }\end{array}$ & $\begin{array}{l}3 \text { March } \\
2017\end{array}$ \\
\hline 31 & Education by headquarters & $\begin{array}{l}\text { Amway's extended 'education' platform: } \\
\text { http://www.amway.com/about-amway/AmwayEducation }\end{array}$ & $\begin{array}{l}6 \text { March } \\
2017\end{array}$ \\
\hline 32 & $\begin{array}{l}\text { Direct Selling Associations } \\
\text { providing overview of } \\
\text { industry merits }\end{array}$ & $\begin{array}{l}\text { World Federation of Direct Selling Associations: } \\
\text { http://wfdsa.org/about-direct-selling/ } \\
\text { Seldia } \\
\text { http://seldia.eu/index.php?option=com_content\&view=article\&id=7\&Itemid=139 } \\
\text { German Direct Selling Association: } \\
\text { Advantages for corporations: http://www.direktvertrieb.de/Vorteile-fuer-Unternehmen.74.0.html } \\
\text { Advantages for (future) distributors: } \\
\text { http://www.direktvertrieb.de/Argumente.106.0.html } \\
\text { Advantages for customers: } \\
\text { http://www.direktvertrieb.de/Vorteile.85.0.html }\end{array}$ & $\begin{array}{l}6 \text { March } \\
2017\end{array}$ \\
\hline
\end{tabular}

\section{References}

Albaum, G., \& Peterson, R. A. (2011). Multilevel (network) marketing: An objective view. The Marketing Review, 11(4), $347-361$.

AMA. (2010). Virtual mentor. American Medical Association Journal of Ethics, 12(12), 925-927.

Amway. (2012). Europäische Richtlinie für Business Support Material (BSM). Amway GmbH. https://www.amway.de/_fileserver/ item/10806/BSM_SEP_2012_de.pdf.

Andrews, J. (2001). Ain't it great? A look inside Amway. Bloomington: 1st Books Library.
Ashforth, B. E., \& Anand, V. (2003). The normalization of corruption in organizations. Research in Organizational Behavior, 25, $1-52$.

Ashforth, B. E., Gioia, D. A., Robinson, S. L., \& Trevino, L. K. (2008). Re-viewing organizational corruption. Academy of Management Review, 33(3), 670-684.

Babener, J. (1998). Direct sales an overview. Chapter 6-The legal environment. Retrieved June 2, 2016, from http://www.mlmle gal.com/chapter.html.

Babu, R. R., \& Anand, P. (2015). Legal aspects of multilevel marketing in India: Negotiating through murky waters. Decision, 42(4), 359-378. 
Bhattacharya, P., \& Mehta, K. K. (2000). Socialization in network marketing organizations: Is it cult behavior? Journal of SocioEconomics, 29(4), 361-374.

Biggart, N. W. (1989). Charismatic capitalism. Direct selling organizations in America. Chicago: The University of Chicago Press.

Bloch, B. (1996). Multilevel marketing: What's the catch? Journal of Consumer Marketing, 13(4), 18-24.

Bone, J. (2006). 'The longest day': 'Flexible' contracts, performancerelated pay and risk shifting in the UK direct selling sector. Work, Employment \& Society, 20(1), 109-127.

Bosley, S., \& McKeage, K. K. (2015). Multilevel marketing diffusion and the risk of pyramid scheme activity: The case of fortune hitech marketing in Montana. Journal of Public Policy \& Marketing, 34(1), 84-102.

Brodie, S., Albaum, G., Chen, D.-F. R., Garcia, L., Kennedy, R., Msweli-Mbanga, P., et al. (2004). Public perceptions of direct selling: An international perspective. Westminster Business School Research Report, 2004, 18-2004.

Brodie, S., Stanworth, J., \& Wotruba, T. R. (2002). Comparisons of salespeople in multilevel vs. single level direct selling organizations. The Journal of Personal Selling and Sales Management, 22(2), 67-75.

Bromley, D. G. (1998). Transformative movements and quasireligious corporations the case of Amway. In N. J. Demerath, P. D. Hall, T. Schmitt, \& R. H. Williams (Eds.), Sacred companies. Organizational aspects of religion and religious aspects of organizations (pp. 349-363). New York: Oxford University Press.

Bundesärtzekammer. (2015). (Muster-)Berufsordnung für die in Deutschland tätigen Ärztinnen und Ärzte-MBO-Ä 1997-in der Fassung des Beschlusses des 118. Deutschen Ärztetages 2015 in Frankfurt am Main. Deutscher Ärztetag. http://www. bundesaerztekammer.de/fileadmin/user_upload/downloads/pdfOrdner/MBO/MBO_02.07.2015.pdf.

Butterfield, S. (1985). Amway. The cult of free enterprise. Boston: South End Press.

Cahn, P. S. (2006). Building down and dreaming up: Finding faith in a Mexican multilevel marketer. American Ethnologist, 33(1), 126-142.

Chonko, L. B., Wotruba, T. R., \& Loe, T. W. (2002). Direct selling ethics at the top: An industry audit and status report. Journal of Personal Selling \& Sales Management, 12(2), 87-95.

Clegg, S. R., \& Gordon, R. D. (2012). Accounting for ethics in action: Problems with localised constructions of legitimacy. Financial Accountability \& Management, 28(4), 417-436. doi:10.1111/j. 1468-0408.2012.00554.x.

Crittenden, V. L., \& Albaum, G. (2015). The misplaced controversy about internal consumption: Not just a direct selling phenomenon. Business Horizons, 58(4), 421-429. doi:10.1016/j. bushor.2015.03.007.

Dean, A. (1996). Consumed by success. Reaching the top and finding God wasn't there... (3rd ed.). Mukilteo: WinePress.

DiMaggio, P., \& Louch, H. (1998). Socially embedded consumer transactions: For what kinds of purchases do people most often use networks? American Sociological Review, 65(5), 619-637.

Droney, D. (2016). Networking health: Multi-level marketing of health products in Ghana. Anthropology \& Medicine, 23(1), $1-13$.

DSE. (2015). DSE code of ethics. 14 July 2015: Direct Selling Europe. http://www.directsellingeurope.eu/sites/default/files/ DSE_Code_of_Ethics.pdf.

DSN. (2012). Direct selling news. 100 Global. Our exclusive annual report. Plano US: Direct Selling News.
Dumoff, A. J. D. (2000). Medical boards' prohibitions against physician supplement sales. Alternative \& Complementary Therapies, 6(4), 226-232.

Fadzillah, I. (2005). The Amway connection: How transnational ideas of beauty and money affect northern Thai girls' (p. 85). Youthscapes: The Popular, the National, the Global.

Franco, W., \& Gonzalez-Perez, M. A. (2016). International expansion opportunities for multi-level marketing via personal networks: An ethnographic study from Columbia. International Journal of Business and Society, 17(1), 28.

Frenzen, J. K., \& Davis, H. L. (1990). Purchasing behavior in embedded markets. Journal of Consumer Research, 17, 1-12.

Friedner, M. (2014). Deaf capital: An exploration of the relationship between stigma and value in deaf multilevel marketing participation in urban India. Medical Anthropology Quarterly, 28(4), 502-518.

Friedner, M. (2015). Deaf uplines and downlines multi-level marketing and disharmonious sociality in urban India. Contributions to Indian Sociology, 49(1), 1-25.

Grayson, K. (2007). Friendship versus business in marketing relationships. Journal of Marketing, 71(4), 121-139.

Greil, A. L., \& Rudy, D. R., (1984). Social cocoons: Encapsulation and identity transformation organizations. Sociological Inquiry, 54(3), 260-278

Groß, C. (2008). Multi-level-Marketing_Identität und Ideologie im Network-Marketing. Wiesbaden: Springer.

Groß, C. (2010). Spiritual cleansing: A case study on how spirituality can be mis/used by a company. Management Revue, 21(1), 60-81.

Groß, C., \& Haunschild, A. (2013). Liberté toujours? Gerechtigkeit und Gemeinschaft in neoliberalen Arbeitsregimen am Beispiel der Amway GmbH. Zeitschrift für Personalforschung, 27(2), 81-102.

Groß, C., \& Jung, N. (2009). Challenging the conventional wisdom on 'enterprise': Control and autonomy in a direct selling organisation. Management Revue, 20(4), 348-372.

Gu, C.-J. (2004). Disciplined bodies in direct selling: Amway and alternative economic culture in Taiwan. In D. K. Jordan, A. D. Morris, \& M. L. Moskowitz (Eds.), The minor arts of daily life: Popular culture in Taiwan (pp. 150-172). Honolulu, HI: Hawaï University Press.

Herbig, P., \& Yelkurm, R. (1997). A review of the multilevel marketing phenomenon. Journal of Marketing Channels, 6(1), $17-33$.

Hyman, M. R. (1990). Deception in advertising: A proposed complex of definitions for researchers, lawyers, and regulators. International Journal of Advertising, 9(3), 259-270.

Hyman, M. R. (2007). Multi-level marketing: A pyramid scheme by design. New Mexico Business Outlook, November, 1-5.

Hyman, M. R. (2009). If it walks like a duck. New Mexico Business Outlook, February, 1-5.

Jackall, R. (1988). Moral mazes: The world of corporate managers. New York: Oxford University Press.

Juth-Gavasso, C. L. (1985). Organizational deviance in the direct selling industry: A case study of the Amway corporation. Ann Arbor: University Microfilms International.

Kalleberg, A. L. (2009). Precarious work, insecure workers: Employment relations in transition. American Sociological Review, 74(1), 1-22.

Keep, W. W., \& Vander Nat, P. J. (2014). Multilevel marketing and pyramid schemes in the United States. An historical analysis. Journal of Historical Research, 6(2), 188-210.

Koehn, D. (2001). Ethical issues concerned with multi-level marketing schemes. Journal of Business Ethics, 29(1/2), 153-160. 
Kong, K. C. (2003). “Are you my friend?”: Negotiating friendship in conversations between network marketers and their prospects. Language in Society, 32(04), 487-522.

Krige, D. (2012). Fields of dreams, fields of schemes: Ponzi finance and multi-level marketing in South Africa. Africa, 82(01), 69-92.

Lan, P. C. (2002). Networking capitalism: Network construction and control effects in direct selling. The Sociological Quarterly, 43(2), 165-184.

Lips-Wiersma, M., Lund Dean, K., \& Fornarciarie, C. J. (2009). Theorizing the dark side of the Workplace spirituality movement. Journal of Management Inquiry, 18(4), 288-300.

Lorenz, M., \& Mazzoni, T. (2010). Quantitative Evaluierung von Multi-Level Marketingsystemen: Fernuniversität Hagen, fernuni.de.

MacLean, T., Litzky, B. E., \& Holderness, D. K. (2015). When organizations don't walk their talk: A cross-level examination of how decoupling formal ethics programs affects organizational members. Journal of Business Ethics, 128(2), 351-368. doi:10. 1007/s10551-014-2103-1.

Mintzberg, H. (1983). Structure in fives: Designing effective organizations. Upper Saddle River: Prentice-Hall.

Muncy, J. A. (2004). Ethical issues in multilevel marketing: Is it a legitimate business or just another pyramid scheme? Marketing Education Review, 14(3), 47-53.

Nelson, J. (2016). The normalization of corruption. Journal of Management Inquiry. doi:10.1177/1056492616675415.

Ogbogu, P., Fleischer, A. B., Brodell, R. T., Bhalla, G., Draelos Zoe, D., \& Feldman, S. R. (2001). Physicians' and patients' perspectives on office-based dispensing. Archives of Dermatology, 137(2), 151-154.

Ouchi, W. G. (1980). Markets, bureaucracies, and clans. Administrative Science Quarterly, 25, 129-141.

Pareja, S. (2008). Sales gone wild: Will the ftc's business opportunity rule put an end to pyramid marketing schemes. McGeorge Law Review, 39, 83.

Peterson, R. A., \& Albaum, G. (2007). On the ethicality of internal consumption in multilevel marketing. Journal of Personal Selling \& Sales Management, 27(4), 317-323.

Peterson, R. A., \& Wotruba, T. R. (1996). What is direct selling? Definition, perspectives, and research agenda. Journal of Personal Selling \& Sales Management, 16(4), 1-16.

Pratt, M. G. (2000a). Building an ideological fortress: The role of spirituality, encapsulation and sensemaking. Studies in Cultures, Organizations and Societies, 6, 35-69.

Pratt, M. G. (2000b). The good, the bad, and the ambivalent: Managing identification among Amway distributors. Administrative Science Quarterly, 45(3), 456-493.

Pratt, M. G., \& Rosa, J. A. (2003). Transforming work-family conflict into commitment in network marketing organizations. Academy of Management Journal, 46(4), 395-418.

Ramirez, E. (2016). Keynote remarks of FTC Chairwoman Ramirez, DSA business \& policy conference, Washington, DC, October 25. Federal Trade Commission (30 October 2016). https://www. ftc.gov/system/files/documents/public_statements/993473/ ramirez_-_dsa_speech_10-25-16.pdf.

Rampelotto, L., \& Schwarz, M. (1999). Das Schwarz-System. Cles (TN): Schwarz Books.

Scheibeler, E. N. (2004). Merchants of deception. An insider's look at the worldwide, systematic conspiracy of lies that is Amway/ Quixtar and their motivational organization. 12 July 2005: Eric N. Scheibeler. www.merchantsofdeception.com.

Schein, E. (1990). Organizational culture. American Psychologist, 45(2), 109-119.
Schwarz, M., \& Schwarz, M. E. (1993). Information, Wissenswertes und Tips zum Geschäftsaufbau. Aufbauhilfe 3: Marianne und Max Schwarz.

Schwarz, M., \& Schwarz, M. E. (2001). Mein Weg zum Kronenbotschafter. Langenmosen: Marianne und Max Schwarz GmbH \& Co., Vertriebsförderungs KG.

Schwarz, M., \& Schwarz, M. E. (2002). Der Erfolgsweg. Langenmosen: Marianne und Max Schwarz GmbH \& Co., Vertriebsförderungs KG.

Scott, L., Dolan, C., Johnstone-Louis, M., Sugden, K., \& Wu, M. (2012). Enterprise and inequality: A study of avon in South Africa. Entrepreneurship Theory and Practice, 36(3), 543-568.

Seldia. (2011). European codes of conduct for direct selling. 14 July 2015: Seldia. The European Direct Selling Association. Available: http://www.seldia.eu/images/pdf/SELDIA3993_Codeof Conduct_02.pdf.

Smith, E. R. (2013). Downline...An Intolerable Potential to Deceive. Dallas: Wordwell.

Smith-Crowe, K., Tenbrunsel, A. E., Chan-Serafin, S., Brief, A. P., Umphress, E. E., \& Joseph, J. (2015). The ethics "fix": When formal systems make a difference. Journal of Business Ethics, 131(4), 791-801.

Sonnabend, U. (1998). Der geliehene Traum. In der Seifenblase zum Kronenbotschafter. München: ZeitGeist Forum.

Sparks, J. R., \& Schenk, J. A. (2001). Explaining the effects of transformational leadership: An investigation of higher-order motives in multilevel marketing organizations. Journal of Organizational Behavior, 22, 849-869.

Sparks, J. R., \& Schenk, J. A. (2006). Socialization communication, organizational citizenship behaviors, and sales in a multilevel marketing organization. Journal of Personal Selling \& Sales Management, 26(2), 161-180.

Taylor, J. M. (2014). Unmasked - The case against MLM as an unfair and deceptive practice. January 1, 2015: Consumer Awareness Institute. Available: http://www.mlm-thetruth.com/files/9714/ 2145/3570/MLMunmasked-1-1-2015.pdf.

Tokaji-Nagy, O. J. (2016). A legal and empirical investigation into the direct selling industry's advocacy in the EU. June 17, 2016: Univeritaire Pers Maastricht. https://cris.maastrichtuniversity.nl/ portal/files/1419198/guid-cced183a-aa58-45a0-b8d1cdf5892d1aef-ASSET1.0.

Vander Nat, P. J., \& Keep, W. W. (2002). Marketing fraud: An approach for differentiating multilevel marketing from pyramid schemes. Journal of Public Policy \& Marketing, 21(1), 139-151.

Walsh, J. (1999a). How ponzi schemes, pyramid frauds work. And why they are more common than ever. Consumers' Research Magazine, 82(6), 10-14.

Walsh, J. (1999b). Multi-level marketing skirts legal lines. Consumers' Research Magazine, 82(6), 12-13.

Weber, M. (1980). Wirtschaft und Gesellschaft. Grundriss der verstehenden Soziologie (5th ed.). Tübingen: Mohr.

Werhane, P. H. (1999). Moral imagination and management decision making. New York: Oxford University Press.

WFDSA (2008). WFDSA Code of Ethics. 14 July 2015: World Federation of Direct Selling Associations. Available: http:// www.wfdsa.org/files/world-codes/code-book.pdf.

WFDSA. (2016). World Federation Statistical Database. December 16, 2016. http://wfdsa.org/global-statistics/.

Whitaker-Worth, D., Shahriari, M., Slade, K., \& Grant-Kels, J. M. (2012). The ethical controversies of office-based dispensing in academic health centers. Clinics in Dermatology, 30, 528-532.

Wotruba, T. R., Chonko, L. B., \& Loe, T. W. (2001). The impact of ethics code familiarity on manager behavior. Journal of Business Ethics, 33(1), 59-69. 